\title{
Uranium Deposits in \\ Grant County, New Mexico
}

By

H. C. Granger, H. L. Bauer, Jr., T. G. Lovering, and Elliot Gillerman

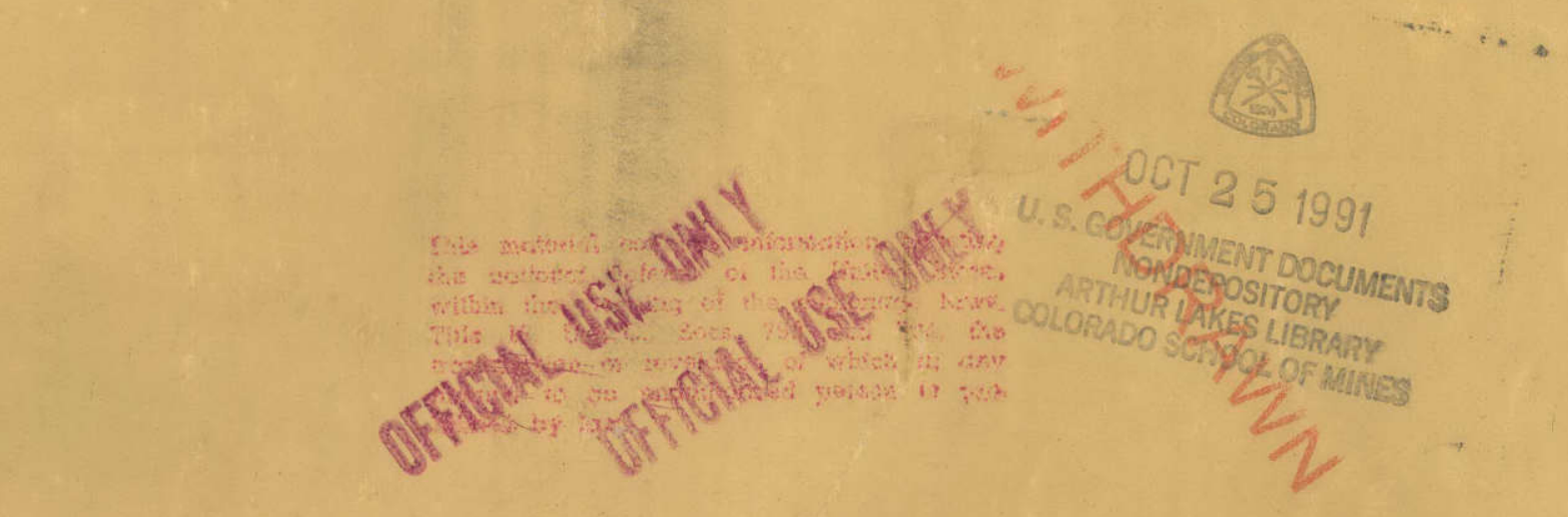

\section{Trace Elements Investigations Report 156}

UNITED STATES DERARTMENT OF THE INTERIOR GEOLOGICAL SURVEY 
\# of copies

DFFICHATHSEDON!

IN REP

UNITED STATES

DEPARTMENT OF THE INTERIOR GEOLOGICAL SURVEY

WASHINGTON 25, D.C.

Document tragmilded herewith contain KclDJified SHCURITY

$: 1953$ INES IAN.

AEC $-732 / 3$

Dr. Phillip L. Merritt, Assistant Director

Division of Raw Materials

U. S. Atomic Energy Commission

P. O. Box 30, Ansonia Station

New York 23, New York

Dear Phil:

Transmitted herewith are six copies of TEI-156, "Uranium deposits

in Grant County, New Mexico," by Harry C. Granger, Herman I. Bauer, Jr.,

Tom G. Lovering, and Elliot Gillerman, September 1952.

We plan to publish Part I as a Geological Survey bulletin. We

are asking $\mathrm{Mr}$, Hosted to approve this plan.

Sincerely yours,

Vi mokeluery

for

V.. H. Bradley

Chief Geologist

U. S. ERA, GJO

Abuquercis: Field Office

Albuquerque, New Mexico

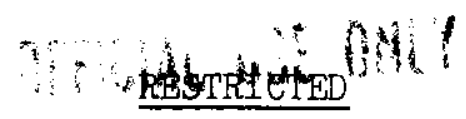


Geology - Mineralogy

This document consists of 65 pages, plus 4 figures.

Series A

\section{UNITED STATES DEPARTMENT OF THE INTERIOR}

GEOLOGICAL SURVEY

URANIUM DEPOSITS IN GRANT COUNTY.NEW MEXICO*

By

Harry $C_{0}$ Granger, Herman $L_{*}$ Bauer, Ir $r_{o}$,

Tom $G$. Lovering, and Elliot $G$ illerman

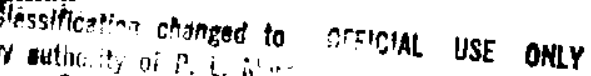

September 1952

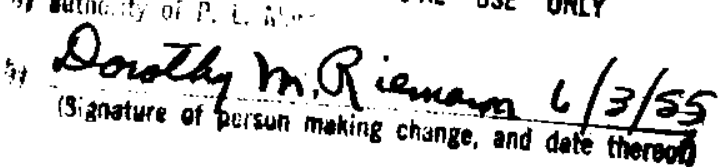

Trace Elements Investigations Report 156

This preliminary report is distributed without editorial and technical review for conformity with official standards and nomenclature. It is not for public inspection or quotation.

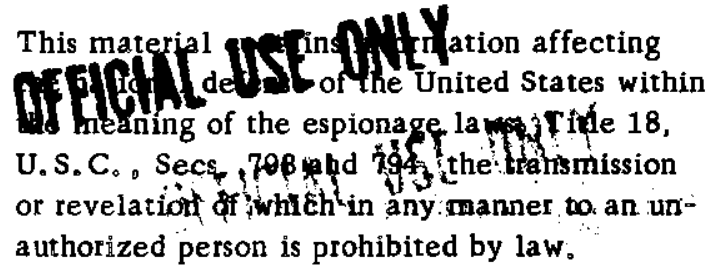

This report concerns work done on behalf of the Division of Raw Materials of the $U_{0}$ S. Atomic Energy Commission

When separated from Part II, handle Part I as UNCLASSIFIED

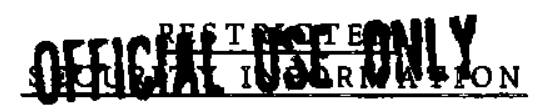


USGS - TEI Report 156

GEOLOG Y - MINERALOGY

Distribution (Series A)

No. of copies

American Cyanamid Company, Winchester ........ 1

Argonne National Laboratory . . . . . . . . . . . 1

Atomic Energy Commission, Washington . . . . . . . 1

Battelle Memorial Institute, Columbus ........... 1

Carbide and Carbon Chemicals Company, Y-12 Area. . . . . 1

Division of Raw Materials, Grants . . . . . . . . . 1

Division of Raw Materials, Denver。 . . . . . . . . 1

Division of Raw Materials, Hot Springs . . . . . . . . 1

Division of Raw Materials, New York。 . . . . . . . 6

Division of Raw Materials, Salt Lake City . ........ 1

Division of Raw Materials, Richfield . . . . . . . . 1

Division of Raw Materials, Butte . . . . . . . . . 1

Division of Raw Materials, Washington .. . . . . . . 3

Dow Chemical Company, Pittsburg ........... 1

Exploration Division, Grand Junction Operations Office . . . . 1

Grand Junction Operations Office . . . . . . . . . 1

Technical Information Service, Oak Ridge, . . . . . . . 6

Tennessee Valley Authority, Wilson Dam . . . . . . . 1

U. S. Geological Survey:

Mineral Deposits Branch, Washington。 . . . . . . . 2

Geochemistry and Petrology Branch, Washington ...... 1

Geophysics Branch, Washington. . . . . . . . . . 1

Alaskan Geology Branch, Washington. . . . . . . . 1

Fuels Branch, Washington ............. 1

L。 Ro Page, Denver ............. 2

R。 Po Fischer, Grand Junction . . . . . . . . . . 1

A. E. Weissenborn, Spokane . . . . . . . . . . 1

Jo Fo Smith, Jr, Denver . . . . . . . . . . . 1

N. M. Denson, Denver. . . . . . . . . . . 1

L。 $S_{\circ}$ Gardner, Albuquerque . . . . . ...... 1

A。 H. Koschmann, Denver ............. 1

E。 Ho Bailey, San Francisco 。. . . . . . . . . . 1

A. F. Shride, Tucson . . . . . . . . . . . . 1

C. E. Dutton, Madison. . . . . . . . . . . 1

Ro A. Laurence, Knoxville . . . . . . . . . . 1

R. Jo Roberts, Salt Lake City. ............ 1

J. D. Love, laramie. ................ 1

TEPCO, Washington.............. 5

(Including master) 


\section{CONTENTS}

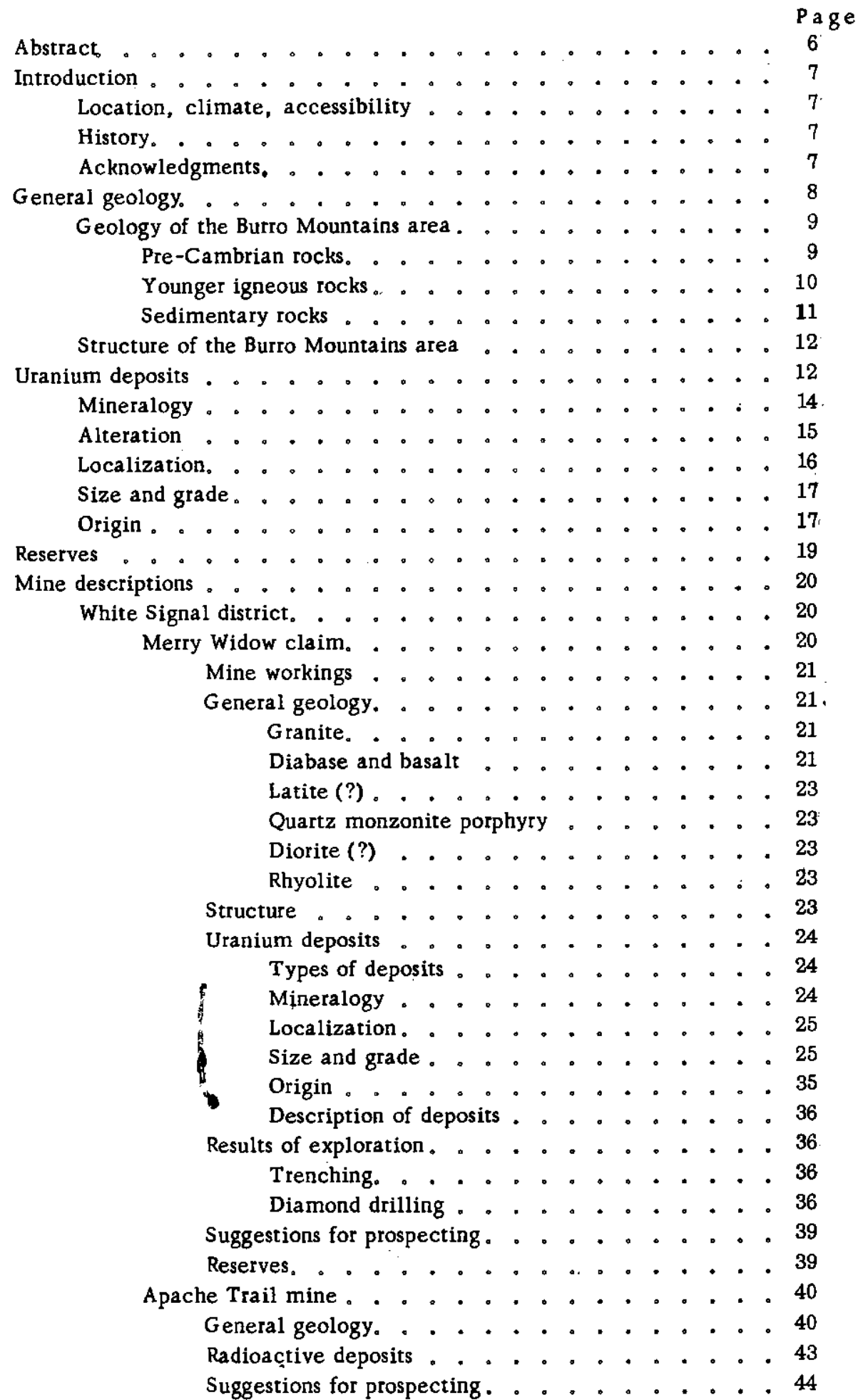




\section{CONTENTS - Continued}

Blue Jay claim $\begin{gathered}\text { P a g } \\ 45\end{gathered}$

General geology。 . . . . . . . . . 45

Granite。 . . . ०... . . . . . . 45

Diabase . . . . . . . . . . . . 45

Basalt . . . . . . . . . . 45

Latite .............. . 46

Aphanitic dikes, . . . . . . . . . 46

Rhyolite .. . . . . . . . . . 46

Veins $. \circ ., 0 . . .0 .0 .0 .046$

Uranium deposits . . . . . . . . . . . . 46

Suggestions for prospecting 。. . . . . . 50

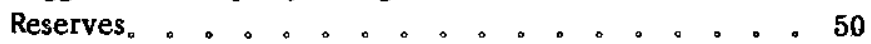

Monarch No, 2 claim ... . . . . . . . 51

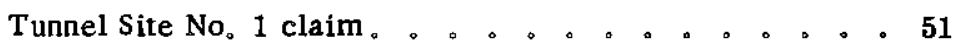

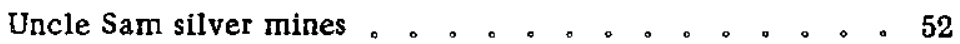

Black Hawk district.. .0 .0 .0 .0 .0 .0 .0 .53$

General geology 。. . . . . . . . . . . 54

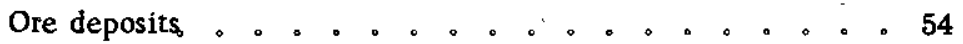

Description of properties . . . . . . . . . . . 54

Black Hawk mine . . . . . . . . . . 54

Alhambra mine . . . . . . . . . . . 55

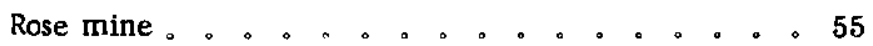

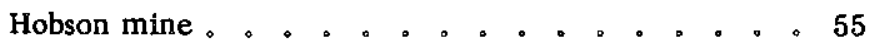

Radioactivity . . . . . . . . . . . . . 55

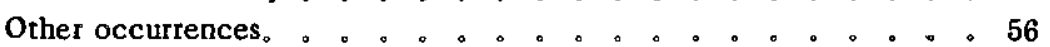

Hines No 1 prospect . . . . . . . . . . 56

Langford prospect . . . . . . . . . . . . . . 59

Uranium occurrences not discussed . $. . .6 .0 . .659$

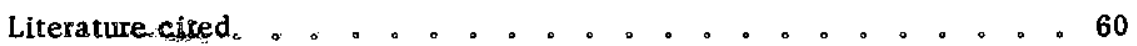

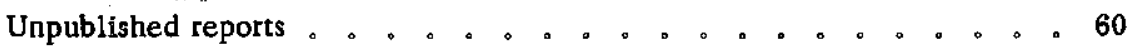

\section{ILLUSTRATIONS}

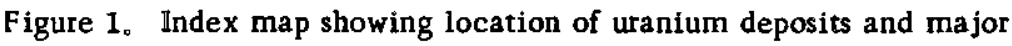
geologic features, Burro Mountains and vicinity. Grant

County, New Mexico。 . . . . . . . . . 13

2. Geologic map, Merry Widow claim, White Signal district,

Grant County, New Mexico ............. In envelope

3. Assay plan, trenches nos, 2, 3, 4, and 5, Merry Widow claim,

White Signal district, Grant County, New Mexico . . . In envelope

4. Detailed geologic map and composite section, trench no. 1 , Merry Widow claim, White Signal district, Grant County,

$\therefore$ New Mexico 
Figure 5. Geologic map, 40-foot and 60-foot levels and composite plan of Merry Widow mine, and White Signal district, Grant County, New Mexico. . . . . . . . . . In envelope

6. Generalized log of diamond drill core, Merry Widow claim, White Signal, New Mexico _. . . . . . . 38

7. Sketch map, Apache Trail claim, Grant County, New Mexico 41

8. Geologic map, 100-foot level, Apache Trail mine, Grant County, New Mexico. . . . . . . . . . 42

9. Geologic map and assay plan of uranium occurrences on Blue Jay claim, White Signal district, Grant County, New Mexico. In envelope

10. Geologic sketch map of the Hines prospect, Grant County, New Mexico . . . . . . . . . . 57

\section{T A B LES}

Table 1. Results of sampling, Merry Widow claim, White Signal district, Grant County, New Mexico 。 . . . . . 26

2. Results of sampling, Merry Widow mine, White Signal district, Grant County, New Mexico . . . . . . 30

3. Radioactive samples from the Merry Widow claim. White Signal district. . . . . . . . . . . . . . 34

4. Sample data, Apache Trail claim ... . . . . . . 44

5. Results of sampling, Blue Jay claim, White Signal district, Grant County, New Mexica . . . . . . . . 47

6. Samples from the Black Hawk district collected and assayed by the U. S. Bureau of Mines. . . . . . . . . . 53

7. Results of sampling, Hines No. 1 prospect, Grant County, New Mexico . . . . . . . . . . . . . 58 


\section{URANIUM DEPOSITS IN GRANT COUNTY, NEW MEXICO}

By Harry C. Granger, Herman L Bauer, Jr. .

Tom G. Lovering, and Elliot Gillerman

\section{A BST RACT}

The known uranium deposits of Grant County, N. Mex, , are principally in the White Signal and Black Hawk districts. Both districts are within a northwesterly-trending belt of pre-Cambrian rocks, composed chiefly of granite with included gneisses, schists, and quartzites. Younger dikes and stocks intrude the preCambrian complex. The White Signal district is on the southeast flanks of the Burro Mountains; the Black Hawk district is about 18 miles northwest of the town of White Signal.

In the White Signal district the secondary uranium phosphates--autunite and torbernite--occur as fracture coatings and disseminations in oxidized parts of quartz-pyrite veins, and in the adjacent mafic dikes and granite; uraniferous limonite is common locally. Most of the known uraniferous deposits are less than 50 feet in their greatest dimension.

The most promising deposits in the district are on the Merry Widow and Blue Jay claims. The richest sample taken from the Merry Widow mine contained more than 2 percent uranium and a sample from the Blue Jay property contained as much as 0.11 percent; samples from the other properties were of lower grade.

In the Black Hawk district pitchblende is associated with nickel, silver, and cobalt minerals in fissure veins. The most promising properties in the Black Hawk district are the Black Hawk, Alhambra, and Rose mines, No uranium analyses of ore from this district were available in 1951.

There are no known minable reserves of uranium ore in either district, although there is some vein material at the Merry Widow mine of ore grade, if a market were available in the region. 


\section{INTRODUCTION}

Location, climate, accessibility

The uranium deposits of Grant County are in the foothills of the Big Burro Mountains in southwestern New Mexico. These mountains are an isolated erosion remnant with a maximum altitude of more than 8,000 feet; they stand about 2,000 feet above a dissected pediment, which slopes gently away in all directions.

The climate is dry and mild; the average annual rainfall is 16 inches, most of which comes in the form of torrential thunder showers during July, August, and September。

The nearest railroad is at Silver City, 18 miles northeast of White Signal. White Signal can be reached by a good paved highway from Silver City; another paved road extends northwestward from Silver City and passes within seven miles of the Black Hawk district. The individual properties are reached by unimproved dirt roads

\section{History}

Gold, silver, and copper were discovered in the White Signal district in the late 1800's; the Black Hawk district was a booming silver camp in the " 80 " $\mathrm{s".} \mathrm{The} \mathrm{rich} \mathrm{ores} \mathrm{in} \mathrm{both} \mathrm{places} \mathrm{were} \mathrm{shallow} \mathrm{and} \mathrm{soon} \mathrm{exhausted,}$ and there has been little mining since that time.

Uranium minerals first were recognized in the area on old mine dumps near White Signal by A. A. Leach (Leach, F。 L. , 1920). Leach (1920) also reported pitchblende from the Black Hawk district, Radiometric

surveys by the $U_{0} S_{\circ}$ Bureau of Mines in 1949 verified the presence of radioactive minerals in the Black Hawk mine.

\section{Acknowledgments}

The field work on which this report is bașed was carried out for the most part by H. C. Granger and H. L. Bauer, $\mathrm{Jr}_{\circ}$, and to a lesser extent by Elliot Gillerman during late 1949 and early 1950 as part of a U. S. Geological Survey program, carried out on the behalf of the Atomic Energy Commission. T. G. Lovering 
compiled the unpublished reports of Granger, Bauer, and Gillerman and, from experience gained during two seasons of field work in Grant County, added sections on general geology, ore deposits, and origin of the uranium deposits, Thanks are due other members of the $U_{0}, S_{0}$ Geological Survey staff, to the personnel of the U. S. Bureau of Mines, and to the property owners for their helpful and friendly cooperation. All analyses, except as noted (tables 2 and 6), were made in the Trace Elements Section Denver Laboratory of the U. S。 Geological Survey。

\section{GENERAL GEOLOG Y}

The geology of Grant County is complex。 The northern part is largely occupied by Tertiary volcanic rocks that form the Mogollon Plateau。The Mimbres or Black Range, along the eastern edge of this Plateau, extends far south into the desert province. Its crest marks the boundary between $G$ rant and Sierra Counties. The western part of this range is made up of Tertiary volcanic rocks and at one place, in Little Gallinas. Canyon, a sample of this rock showed abnormal radioactivity, although no uranium minerals were identified.

Along the southern edge of the Mogollon Plateau $u_{v}$ west of the Black Range, Cretaceous and Paleozoic sedimentary rocks are exposed in irregular strips and patches. These rocks have been complexly faulted, and intruded by a number of stocks, sills, and dikes of Laramide and younger age. The great deposits of silver, copper lead, zinc, and iron, for which Grant County is famous, are largely grouped in and near these centers of intrusion. A few crystals of torbernite have been found in the Chino copper pit disseminated in a granodiorite stock,

South of this irregular belt of sedimentary rocks much of the county is covered by Tertiary and Quarternary alluvium, which floors the wide valleys. Scattered mountain masses, composed of various rock types, protrude through this sedimentary cover. These include: Lone Mountain, made up chiefly of Paleozoic sediments; the Little Burro Mountains, a complex fault block of pre-Cambrian rocks, Cretaceous sedimentary rocks and intrusives; and the Big Burro Mountains, composed for the most part of pre-Cambrian igneous and metamorphic rocks which have been invaded by a quartz monzonite stock at Tyrone. The Big Burro Mountain area includes the two most important uranium districts in the county--White Signal and Black Hawk.

The Big and Little Hatchet Mountains and the Animas Range, in the southernmost part of the county, consist of tilted and faulted Paleozoic limestones and Cretaceous shales and sandstones, which at many places 
are intruded by granitic porphyries. Radioactivity has been reported from the Eureka district in the Little Hatchet Mountains, but its cause has not been ascertained.

The only uranium occurrences of economic interest now known in the county are in the vicinity of the Big Burro Mountains, and accordingly only the geology of this area is discussed in the sections that follow.

\section{Geology of the Burro Mountains Area}

The White Signal and Black Hawk districts are in a region underlain largely by rocks of pre-Cambrian age. These rocks consist chiefly of metasediments and granites that have been invaded by a large quartzmonzonite stock at Tyrone and by numerous dikes, small stocks, and plugs, ranging from basalt to rhyolite in composition. A few small erosion remnants of Paleozoic sedimentary rocks, such as the Bliss sandstone (?) of Cambrian age at the Hines No, 1 property, are widely scattered through the region. In addition, the trough between the Malone Fauit and the parallel fault two miles to the east of it contains pyroclastic and volcanic rocks, which are presumably of Tertiary age. These rocks have not yet been studied in detail, and none of the known uranium deposits are associated with them. Within the same area are tilted, partly consolidated sands and gravels that have been tentatively correlated with the Pliocene (?) Gila conglomerate of Arizona.

$$
\text { Pre-Cambrian rocks }
$$

The oldest rocks in the area--schists, gneisses, and quartzites--are included as xenoliths within preCambrian granite. Isolated masses of these rocks are found in the vicinity of the Black Hawk district but none have been recognized near White Signal.

Granite, the most abundant rock in the region, is variable in composition and consists of several distinctive types. Some types represent separate intrusions, but others may be differentiates of a single granite magma.

The oldest of the granitic rocks exposed in the Black Hawk district--the granite gneiss--is a distinctive, gray, porphytitic granite that has a conspicuous foliation. Hornblende, and biotite that is partly altered to chlorite, constitute 25 to 30 percent of the rock; quartz, orthoclase, and minor amounts of plagioclase make up the remainder. Large orthoclase phenocrysts, as much as an inch in diameter, are abundant throughout 
the mass. Hornblende-biotite granite, which is similar in composition, but which lacks the conspicuous foliation, crops out a few miles south of the Black Hawk district and may be equivalent to this granite gneiss.

A pink, fine-to medium-grained, equigranular granite intrudes the porphyritic granite gneiss in the Black Hawk district. This granite consists essentially of quartz and orthoclase with minor amounts of biotite and plagioclase feldspar; magnetite is a sparse accessory mineral. The granite in the White Signal district varies from fine- to medium-grained, and from pink and grayish orange to buff. This rock consists essentially of quartz, potash feldspar, and biotite, with minor amounts of albite; apatite, sphene, and magnetite are accessory minerals.

Aplites, pegmatites, and quartz veins, which appear to be late differentiates of the magma or magmas that consolidated to form the granites, cut the granite.

Diabase and basalt dikes that strike north or northwest are common in the White Signal district. These dikes are cut by all other dike rocks in the area, and accordingly are tentatively assigned to the pre-Cambrian. The fresh diabase and basalt are dark brown to black and fine- to medium-grained. They are composed essentially of andesine and homblende; magnetite and apatite are common accessory minerals; chlorite and epidote are locally abundant secondary minerals.

\section{Younger igneous rocks}

Younger dike rocks, of varying composition, trend easterly and cut the diabase and basalt dikes in the vicinity of White Signal. These dikes, in approximate age sequence from oldest to youngest, are: latite, andesite porphyry, dacite porphyry, older rhyolite, quartz monzonite porphyry, diorite, quartz diorite, and younger rhyolite。

Highly altered, light to dark gray, aphanitic dikes on the Merry Widow (fig, 2) and Blue Jay (fig. 9) claims were mapped by Granger and Bauer as latites, although they have been so thoroughly argillized that their original composition is obscure.

Andesite porphyry and dacite porphyry dikes cut the older latite and diabase dikes. The andesite and dacite porphyries are typically aphanitic and in places contain phenocrysts that constitute as much as 50 percent of the rock. The phenocrysts are predominantly small white crystals of oligoclase and dark greenish, chloritized flakes of biotite in a dark-gray groundmass. 
The quartz monzonite porphyry dikes in the area are typically leucocratic, porphyritic rocks with large hexagonal quartz crystals and poikilitic phenocrysts of pink orthoclase. Biotite and small white plagioclase phenocrysts are also present. Magnetite and apatite are common accessories. Gillerman (1952) has distinguished two variants of these dikes, according to the character of the biotite and the presence or absence of sphene.

A dark fine-grained rock on the Merry Widow claim, termed diorite by Granger and Bauer, is intermediate in age between the quartz monzonite dikes and the late white rhyolite dikes.

In the Black Hawk district fine- to medium-grained quartz diorite dikes cut the granite. The fresh rocks are pinkish gray。

Two types of white rhyolite dikes have been recognized in the vicinity of the Big Burro Mountains. The older rhyolite dikes predate the quartz monzonite dikes; the younger dikes are among the youngest rocks in the area. The younger dikes seem to be related to small rhyolite plugs and possibly to Tertiary volcanism, which covered the country to the south and west with a thick series of flows. The two types of dikes are difficult to distĭnguish in the field. The younger dikes, however, are commonly more ropy-looking and platy, and flow banding is better developed than in the older dikes. Quartz phenocrysts that are common in the older dikes are rare in the younger dikes, and epidote which may be present in the older dikes is not found in the younger dikes. The presence of epidote is actually the only reliable criterion for distinguishing the older dikes from the younger.

Sedimentary rocks

A few isolated erosion remnants of quartzite of Cambrian age crop out to the south and east of the Burro Mountains。 A small erosional remnant of quartzite at the Hines No。 1 prospect has been tentatively correlated with the Bliss sandstone--of Upper Cambrian age - which forms the base of the sedimentary sequence to the north and east, near Silver City and Santa Rita。

Quartzite and shale of Cretaceous age cap the Little Burro Mountains a few miles north of White Signal, and semiconsolidated gravels of Tertiary and Quaternary age are found at various places around the flanks of the Burro Mountains. No uranium minerals have been found in either the Cretaceous sedimentary rocks or the younger gravels。 


\section{Structure of the Burro Mountains area}

The most prominent structures in the Burro Mountain area are three major northwest-trending normal faults--the Mangas, the Malone, and an unnamed fault 2 miles northwest of the Malone fault (fig. 1). The Mangas fault is a high-angle normal fault that trends northwest and dips about $70^{\circ} \mathrm{SW}$. Late Tertiary and Quaternary gravels are on the southwest (down thrown) side of the fault, and pre-Cambrian granite, Cretaceous and Tertiary volcanics, and Cretaceous sedimentary rocks are on the northeast side. The Malone fault is parallel to the Mangas fault, but it dips steeply to the northeast. Pre-Cambrian granites on the southwest side of the Malone fault are against Tertiary volcanics on the northeast. These volcanics dip about $70^{\circ}$ NE. in the northern part of the belt and about $45^{\circ} \mathrm{NE}$ 。 in the southern part. The unnamed fault, 2 miles northeast of the Malone fault, is parallel to the Mangas and Malone faults. It probably dips southwest and brings the Gila conglomerate of Pliocene (?) age on the southwest against pre-Cambrian granite on the northeast.

Within the White Signal district there are several easterly-trending faults, many of which have been filled by veins. These are cut by another set of faults that strike $\mathrm{N}_{0} 15^{\circ}-30^{\circ} \mathrm{W}_{\circ}$ and contain dikes or veins in some places. This fault pattem probably developed before the intrusion of the quartz monzonite stock at Tyrone. Deposition of the veins, however, may be much later than the faulting.

In the Black Hawk district the prevailing trend of the dikes is northeast but locally it is north or east. No major folds have been recognized in the Burro Mountains area, but further study may disclose their presence.

\section{URANIUM DEPOSITS}

The uranium deposits in Grant County are largely in two districts--the White Signal and the Black Hawk--near the Big Burro Mountains in the southwest central part of the county. Uranium has been reported also from the Hines No, 1 and langford prospects south and southeast of White Signal, the Chino copper pit near Santa Rita, Little Gallinas Canyon in the Black Range, and the Eureka district in the Little Hatchet Mountains, but except for the Hines No. 1 and Langford deposits, little is known of these occurrences, and no published information on them is available. 


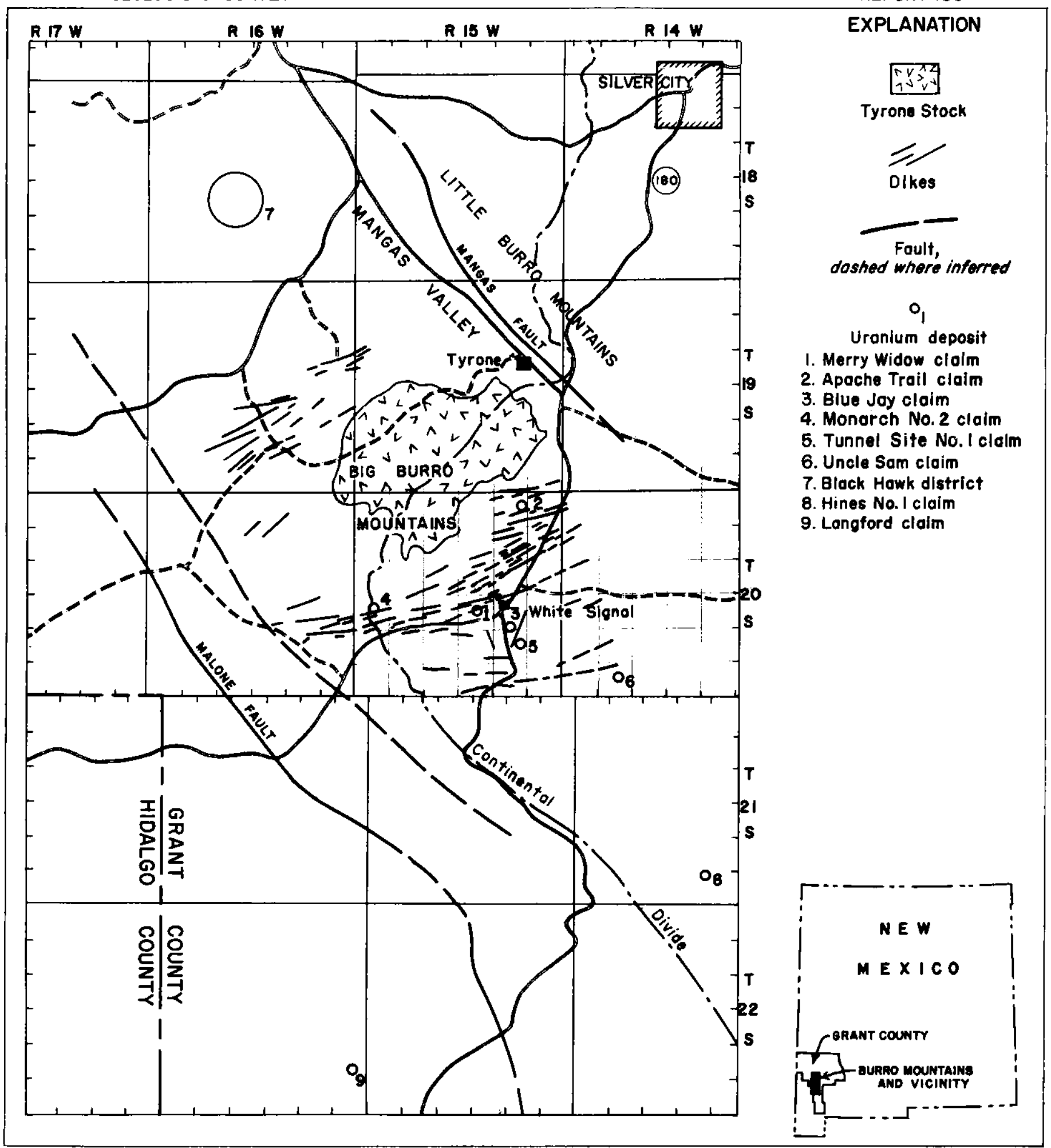

FIGURE I.-INDEX MAP SHOWING LOCATION OF URANIUM DEPOSITS AND MAJOR GEOLOGIC FEATURES, BURRO MOUNTAINS AND VICINITY 


\section{Mineralogy}

The uranium in the White Signal district is in the secondary phosphates autunite and torbernite and also in uraniferous limonite, but no primary minerals have been recognized. The nickel, cobalt, silver, and bismuth sulfides in carbonate gangue, in the Black Hawk district are highly radioactive, and pitchblende was reported from this district by Leach (1920). Torbernite is sparsely disseminated in granodiorite at the Chino copper pit and autunite has been found with fluorite in two small prospects in the southern part of the county. No other recognizable uranium minerals have been reported from the other radioactive deposits in Grant County。

The copper uranium phosphate, torbernite, and the calcium uranium phosphate, autunite, are the only uranium minerals that have thus far been identified in the White Signal district, although an unidentified secondary uranium mineral has been found as an amorphous yellow powder coating fractures in a basic dike on the Blue Jay claim. Autunite is locally predominant near the surface and torbernite at depth, but this zoning is by no means complete. These minerals have been found as much as 185 feet below the surface. Pyrite, chalcopyrite, galena, gold, sphalerite, and bismite are recognized locally in the quartz-pyrite veins where they have been protected from oxidation by a silicified cap.

Pitchblende had been reported from the Black Hawk and Alhambra mines (Leach, 1920) in the Black Hawk district. The Black Hawk dump was examined carefully by Granger and Bauer and a few specimens of carbonate gangue containing small amounts of metallic sulfide were found。According to Leach (1917) the gangue in the vein consists of carbonates, in part silicified to fine-grained jasperoid. Native silver and argentite are associated in the veins with niccolite, nickel-skutterudite, smaltite, galena, sphalerite, chalcopyrite, and pyrite.

On the Hines No. 1 property southeast of White Signal small crystals of a yellow, fluorescent mineral, tentatively identified as autunite, are found in the vicinity of white, violet, and purple fluorite. The same two minerals are associated with pink calcite at the Langford prospect south of White Signal. The dark purple fluorite at this locality is radioactive. 


\section{Alteration}

Hydrothermal alteration of the country rock is common in the vicinity of each of the uranium deposits in the White Signal district. The andesite porphyry, dacite porphyry, diorite, diabase, and latite dikes appear to be more highly altered than the rhyolite, quartz monzonite, and granite. Only some of the rhyolite dikes are altered, which suggests that they may be in part post-alteration in age.

The two most common types of alteration adjacent to uranium-bearing veins are argillization and secondary iron-oxide staining. The greenish alteration of rhyolite at the Merry Widow and Tunnel Site No. 1 claims might be the result of the formation of either secondary chlorite or epidote, probably the latter, by hydrothermal solutions. Sericitization of the wall rock seems to be closely confined to the vicinity of the quartz veins and probably represents a more intense alteration stage than the pervasive argillization. This alteration pattern, around quartz fissure veins in non-calcareous gangue and wall rocks, is a familiar one that is repeated many times in western mining districts. In studies of wall rock alteration at Santa Rita, Kerr, et al. $(1950$, p. 275-347) concluded that the sericite forms later than the clay minerals, probably in a less acid environment at or near the close of sulfide mineralization.

The abundance of limonite indicates secondary alteration by acidic ground waters high in ferric iron. Both the ferric sulfate and the acidity would result from oxidation of pyrite at or near the surface, according to the reaction: $6 \mathrm{FeS}_{2}+6 \mathrm{O}_{2}+4 \mathrm{H}_{2} \mathrm{O}=3 \mathrm{Fe}_{2}\left(\mathrm{SO}_{4}\right)_{3}+4 \mathrm{H}_{2} \mathrm{SO}_{4}$. Ferric sulfate which is unstable in the presence of an excess of water would break down to ferric hydroxide and more sulfuric acid: $\mathrm{Fe}_{2}\left(\mathrm{SO}_{4}\right)_{3}+$ $6 \mathrm{H}_{2} \mathrm{O}=2 \mathrm{Fe}(\mathrm{OH})_{3}+3 \mathrm{H}_{2} \mathrm{SO}_{4}$. Ferric hydroxide precipitates as a flocculent gelatinous mass and on partial dehydration gives limonite $4 \mathrm{Fe}(\mathrm{OH})_{3}=2 \mathrm{Fe}_{2} \mathrm{O}_{3} \cdot 3 \mathrm{H}_{2} \mathrm{O}+3 \mathrm{H}_{2} \mathrm{O}$ 。

Primary uranium oxides are slightly soluble in weak solutions of sulfuric acid, breaking down to form soluble uranium sulfates。Thus, acid ground waters of this type could easily transport uranium in solution. The radioactivity of some of the limonite gossans in the White Signal district lends support to the theory that the ferric hydroxide which formed them was precipitated from uraniferous ground waters. 


\section{Localization}

In both the White Signal and Black Hawk districts uranium appears to be localized by veins that cut pre-Cambrian rocks. The autunite on the Hines No, 1 and Langford prospects is associated with fluorite in breccia-filled fissures in Cambrian and pre-Cambrian rocks respectively. Other radioactive localities in the county have not been investigated sufficiently to determine what factors controlled the mineralization.

No primary uranium minerals have yet been found in the White Signal district; consequently the factors that effected their localization are open to speculation. The hypothesis that primary uranium minerals at depth are concentrated within the quartz-pyrite fissure veins is suggested by the distribution pattern of secondary uranium minerals relative to these veins and to basic dikes near the surface. The alternate hypothesis that the primary uranium concentration is in the basic dikes, is open to the criticism that no primary concentrations of uranium minerals have ever been found in such dikes and that basic rocks as a group contain less uranium than acidic rocks. The similarity of the geologic setting at White Signal with that of deposits containing pitchblende in the Front Range mineral belt of Colorado suggests that the primary uranium minerals at White Signal probably occur with base metal sulfides in the quartz fissure veins below the zone of oxidation.

The secondary uranium minerals in the White Signal district are localized by some fissure veins and faults and by basic dikes. Three types of veins are present in the area: barren quartz veins, with which no uranium is associated; quartz-hematite veins, which contain low-grade uranium in a few places such as the Apache Trail property; and quartz-pyrite veins, which contain a few hundredths of a percent of uranium in many places on the Blue Jay and Merry Widow claims, The diabase, basalt, and latite dikes contain much more secondary uranium than do the veins (table 3) but the highest uranium content in these dikes is along fracture zones near the larger veins and faults and near the granite contacts. Some secondary uranium minerals are also found in the granite along fractures near the dikes but the granite is a much less favorable host rock than the dikes. This distribution pattern suggests that at depth the secondary uranium deposits should occur along the intersections of dikes with faults, fissure veins, and shear zones and should plunge in the same direction as these intersections. 
The distribution of uranium below the water table in this district is not known because the water table is at a depth of more than 500 feet and the deepest accessible workings are only 100 feet deep. The zone of intense oxidation, which appears to be most favorable to the concentration of secondary uranium minerals, extends to a depth of about 100 feet in the White Signal district.

In the Black Hawk district, uranium is closely associated with silver and lead minerals in fissure veins whose wall rocks show neither abnormal radioactivity nor secondary uranium minerals. These sulfide-bearing quartz-carbonate fissure veins, in part uraniferous, cut pre-Cambrian rocks over an area of nearly 4 square miles. Their trend, though variable, is predominantly northerly or northeasterly. These veins are not resistant to weathering and consequently their surface exposures are inconspicuous.

\section{Size and grade}

Most of the known uranium deposits in the White Signal district are small, rudely tabular bodies a few feet in width and a few tens of feet in length and depth, through which the uranium is erratically distributed. The tenor of these bodies commonly ranges from a few thousandths to a few hundredths of a percent uranium. An exception to this generalization is the Merry Widow vein zone which extends for nearly 1,000 feet on the surface, is mineralized to a depth of about 200 feet, and is as much as 50 feet thick. The uranium minerals are irregularly distributed within this zone but although selected specimens contain more than 2 percent uranium $_{\mathrm{v}}$ most of the vein zone is less than 0.1 percent.

All the mine workings in the Black Hawk district were inaccessible at the time of examination. Consequently no estimates of the size, distribution, and grade of uranium deposits in this district could be made。

\section{Origin}

In the White Signal district the secondary uranium minerals probably were derived from quartz-pyrite fissure veins, During weathering the primary minerals seem to have been altered, and the uranium carried in solution in slightly acid ground waters to be redeposited near the surface. In the Black Hawk district the close association of pitchblende with primary lead, silver, copper, and cobalt minerals and the absence of autunite 
and torbernite suggests that the veins were not leached under the same environment as the veins in the White Signal district.

In the White Signal district the known uranium minerals occur as late secondary coatings of cracks, disseminations, and fillings of voids; no primary uranium minerals have yet been found. These facts suggest that the uranium was transported in solution from its primary source. Uranium oxides, in the presence of pyrite and other sulfides go into solution in ground water as the soluble uranium sulfate, and may be carried for some distance before being reprecipitated. The only abundant uranium minerals in the district are the phosphates, autunite and torbernite. This suggests that high concentrations of phosphate in the country rock may have localized the uranium deposits; an inference which is supported by the fact that the diabase and basalt dikes, in which many of the uranium bodies are concentrated, contain approximately ten times as much $\mathrm{P}_{2} \mathrm{O}_{5}$ as do the granites and felsic dike rocks. The granites contain an average of about 0.2 percent $\mathrm{P}_{2} \mathrm{O}_{5}$. whereas the mafic dike rocks may contain as much as 3 percent (table 1)。 The hypothesis that these dike rocks are genetically related to the primary source of the uranium is open to the argument that mafic igneous rocks as a group contain much less uranium than do the more felsic varieties. According to Rankama and Sahama (1950, p. 634), basic igneous rocks contain an average of $0.96 \mathrm{~g}$ of uranium per ton and granitic rocks contain an average of $3.963 \mathrm{~g}$ of uranium per ton. According to Davidson (1949) "weathered basic dikes containing autunite and torbernite are of very frequent occurrence in uranium country; but in every case that has been examined, the mineralization is entirely secondary, attributable to infiltration and not derived from the basic magma."

Ferric hydroxide precipitates from solution as a flocculent, gelatinous mass that readily adsorbs other metallic ions, On partial dehydration, ferric hydroxide yields limonite. The fact that the limonite gossans, in many places in the White Signal district, are uraniferous may thus be taken as an indication that uranium was distributed by the ground waters from which these gossans were derived.

Pitchblende is associated with pyrite and chalcopyrite in quartz fissure veins cutting pre-Cambrian granites in other areas such as the Front Range Mineral Belt of Colorado. The original source of uranium in the White Signal district may, therefore, reasonably be ascribed to uranium oxides in the deeper unoxidized portions of the quartz-pyrite-chalcopyrite fissure veins. 
The ultimate source of uranium in both the White Signal and Black Hawk districts is extremely speculative. It may be supposed that the uranium, as well as the other metals whose minerals are found in these districts, were differentiated at a late stage in the cooling of the magma or magmas which gave rise to the stocks and dikes。

The occurrence of cobalt, nickel, and silver minerals in a carbonate gangue suggests a similarity between deposits in the Black Hawk district and those at Great Bear Lake, Northwest Territories, Canada (Kidd and Haycock, 1935).

A specimen of high-grade native silver ore from the Black Hawk mine was tested with a Geiger counter; it registered a deflection of 15 divisions on the 2.0 scale as compared with a background count of 4 divisions on the 0.2 scale, (approximately 38 times the background count)。

The age of the uranium minerals in the White Signal district is uncertain。 The quartz-pyrite veins cut dikes younger than the quartz-monzonite stock at Tyrone, which is similar to stocks of Laramide age in the Santa Rita quadrangle and is thus presumed to be approximately contemporaneous with them。 Secondary uranium minerals coat fractures in the quartz veins so it seems probable that these deposits are not older than Tertiary and may be very recent.

The age of the ore deposits at Black Hawk is unknown. If these deposits are genetically related to the stocks or dikes in the vicinity they are presumably late Cretaceous or early Tertiary.

\section{RESERVES}

The only property in Grant County with known uranium reserves of ore grade is the Merry Widow mine in the White Signal district. The richest part of this deposit is within the Merry Widow vein zone and close to the Merry Widow shaft, Samples from this mine contain as much as 1.74 percent uranium. The grade of the other known uranium occurrences in the county appear to be too low for economic exploitation under conditions existing in 1952. The numerous small occurrences of uranium minerals in many parts of Grant County suggest that the reserves might be greatly increased by further prospecting。 


\section{MINE DESCRIPTIONS}

\section{White Signal district}

Most of the mines and prospects in the White Signal mining district are in $T_{\circ} 20 \mathrm{~S}_{\circ}, \mathrm{R}_{\circ} 15 \mathrm{~W}_{0}$, New Mexico principal meridian within a few miles of the store and postoffice of White Signal.

Gold, silver, and copper minerals were found in the White Signal district in the late 1800's (Keith, 1945) and mining activity began on the Merry Widow, Apache Trail. Tunnel Site, and Uncle Sam proper-

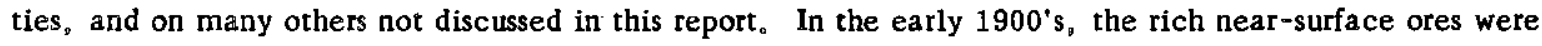
mined out, and since that time production has been small ${ }_{\mathrm{v}}$ About 1920 secondary uranium minerals were recognized on old dumps by $A . A$. Leach, and offers of $\$ 50,00$ per ton for 0.5 to 3 percent uranium ore revived mining activity. The uranium minerals, autunite and torbernite, were embedded in plaster plaques to be used in activating water for drinking, bathing, and watering plants Two carloads of torbernite, clay, and sericite from the Merry Widow mine were produced for the manufacture of radioactive face powder. Neither of these enterprises was successful, In 1944 and 1945, the Union Mines Development Corporation made two examinations (Keith, 1944; 1945) of the uranium deposits in the White Signal district. Post-war interest in uranium again revived prospecting activity。 At the request of the $U_{0} S_{0}$ Atomic Energy Commission, Granger and Bauer of the $U_{0} S_{0}$ Geological Survey examined several of the known uraniumbearing deposits in the area during late 1949 and early 1950 .

$$
\text { Merry Widow claim }
$$

The Merry Widow claim (fig, 1 ) is near the center of sec, 22, T, $20 \mathrm{~S}_{\circ}, \mathrm{R}_{\circ} 15 \mathrm{~W}$, New Mexico principal meridian. It is 0.7 mile by dirt road northwesterly from the Silver City-Lordsburg highway at a point about 0.5 mile west of White Signal. The Merry Widow is one of a block of 6 claims, the Acme, Acme No. 1, Merry Widow. Merry Widow No. 1, Ace in the Hole, and Deuce in the Hole, controlled by A. G. Hill of Dallas, Tex。

The Merry Widow mine was located in the $1880^{\prime}$ 's as a gold property and was operated until exhaustion of the easily accessible ores in the early 1900's forced suspension of mining activity. Following the discovery 
of uranium in the district, the mine was reopened during the 1920's and two carloads of ore containing a mixture of autunite, torbernite, sericite, and clay were shipped, This venture proved unprofitable, the mine was again closed down and no further shipments are recorded。

The mine workings were examined and sampled for uranium by Keith (1945). During February and March 1950, a geologic map on the scale of 1 inch equals 100 feet was made of the Merry Widow claim (fig. 2) by Granger and Bauer. Five exploration trenches, and the 40-and 60-foot levels of the Merry Widow mine (fig. 5) were mapped on a scale of 1 inch equals 10 feet, and 133 samples (table 1) were collected. Only the map of one trench--No. 1--(fig。 4) has been included in this report. During May 1950, diamond drilling was done on the Merry Widow claim by the owner and 650 feet of drill core was logged by $G$ ranger and Bauer。

\section{Mine workings}

The Merry Widow mine consists of a 150 -foot shaft inclined from $65^{\circ}$ to $72^{\circ}$ to the southeast, and about 450 feet of workings on four levels at $40,60,90$, and 130 feet $_{0}$ in 1950 the mine was inaccessible below the 60-foot level. Both the 40- and 60-foot levels were mapped on a scale of 1 inch equals 10 feet (fig. 5).

In addition to the mine workings, 5 shallow trenches have been excavated on the claim (fig。2).

\section{General geology}

The Merry Widow claim is in an area underlain by a large pre-Cambrian granite mass that is intruded by numerous dikes ranging from basalt to pegmatite in composition.

Granite ${ }_{0}=$ The granite that forms the country rock in the vicinity of the Merry Widow claim (fig. 2) is typically medium-grained but locally coarse-grained to porphyritic. It is composed essentially of feldspar and quartz, with less than 5 percent biotite. The feldspars are partly argillized.

Diabase and basa1t. $\cdots$ Two prominent diabase dikes and several thin basalt dikes (fig. 2), probably of the same age, are exposed on the Merry Widow claim. The dikes strike northeast and dip southeast. The diabase dikes, which are as much as 35 feet thick, have narrow chilled borders, less than 3 feet thick, that are similar in texture to the basalt dikes. Centers of the diabase dikes have a coarse ophitic texture. A thick blanket of dark soil covers the diabase except near a vein where it is commonly hardened by iron oxides. 

Latite (?). --Several altered, gray, aphanitic dikes cut both the diabase and granite on the Merry Widow claim. These dikes, referred to as latite (?), are almost completely altered to clay minerals. The latite (?) dikes strike easterly on the south side of the claim but strike northeasterly on the north half of the claim, and accordingly the dikes may be of different age. They are concealed at the surface and can be seen only in mine workings and prospect pits.

Quartz monzonite porphyry. --Prominent northeasterly-trending dikes of quartz monzonite porphyry (fig。 2) cut the granite in the northern part of the Merry Widow claim. Quartz phenocrysts up to $8 \mathrm{~mm}$ across cut the finer groundmass。

Diorite (?) - Three small exposures of a dark fine-grained rock, tentatively identified as diorite (?) (fig.2) were mapped. The exposures were irregular and discontinuous and no relationships with other rocks were apparent.

Rhyolite - A series of aphanitic, greenish rhyolite dikes, exposed in an easterly-trending zone (fig. 2), are believed to be the most recent intrusive rocks on the Merry Widow claim. Although exposures are common, no normal contacts were seen. Other shyolite dikes in the district commonly have a strike slightly north of east, but the individual dikes on the Merry Widow claim strike northwesterly.

\section{Structure}

The rocks on the Merry Widow claim have been complexly faulted and fractured. Displacement, however, can be seen only where the larger faults offset dikes, as much as 60 feet in some places. In the southern half of the claim these faults have prevailingly easterly trends although in the northern half, most of them strike northerly or northwesterly. The significance of this change in the fault pattern is not known. Most of the faults have steep dips, varying between $60^{\circ}$ and vertical.

Faults on the Merry Widow claim are commonly filled by quartz and limonite vein material or by intrusive rocks. Many of them are characterized by limonite filling or wide altered zones rather than by breccia, slickensides, or other direct evidence of faulting. Many minor faults are so well cemented by quartz and minor amounts of limonite that they are very inconspicuous.

Joints on the Merry Widow claim show no persistent trend; locally joints may have a uniform strike, but another conflicting set may appear a few feet away. The persistent joint sets commonly have the same 
attitude as nearby faults or dikes suggesting that they may be minor fractures in shear zones.

\section{Uranium deposits}

Most of the uranium on the Merry Widow claim is in the easterly striking Merry Widow vein zone, although small patches of uranium-bearing rock are widely scattered throughout the area. The highest uranium assays in the Merry Widow vein zone were obtained within a hundred feet of the Merry Widow shaft.

Types of deposits. --Veins of three distinct types occur on the Merry Widow claim. The barren quartz veins (1), and quartz-hematite (specularite) veins (2), which apparently contain no metallic element other than iron, are less common than the quartz-pyrite veins (3). Uranium is associated with these quartzpyrite veins (fig。2)。 Pyrite in the quartz-pyrite veins near the surface is thoroughly oxidized to limonite. Granite wall rock bordering the veins is stained by hydrous iron oxides and either silicified or intensely altered clay minerals and minor sericite in most places. Fracture zones are filled with massive vitreous or cellular limonite containing scattered masses and blebs of vein quartz.

Most of the diabase cut by the veins is impregnated with silica, and with hydrous iron oxide which, locally, is relatively resistant to weathering.

Minera logy - $^{-H y d r o u s ~ i r o n ~ o x i d e s ~ a r e ~ a b u n d a n t ~ i n ~ t h e ~ n e a r-s u r f a c e ~ p a r t s ~ o f ~ t h e ~ v e i n s ~ o n ~ t h e ~ M e r r y ~}$ Widow claim, Limonite, either massive with conchoidal fracture or vesicular, occurs as a filling in many of the veins. The pulverulent form of limonite is also common, and in places invades the altered rhyolite. Limonite in and near the vein was produced by oxidation of pyrite, and perhaps of chalcopyrite. Pyrite may be found near the surface where shielded from alteration, as within the masses of vein quartz.

Bismite (bismuth trioxide), associated with small pockets of high-grade gold ore, has been reported from the Merry Widow mine but none was recognized by Granger and Bauer.

Some green minerals, exposed on the walls of the Merry Widow mine, are believed to be copper sulfates. They are similar in appearance to torbernite and may easily be confused with it.

Secondary uranium minerals occur at several localities on and near the Merry Widow claim. In the field, the flaky yellow fluorescent uranium minerals were called autunite and the flaky or tabular green weakly fluorescent and nonfluorescent uranium minerals were called torbernite. No distinction was made between torbernite and metatorbernite. 
Localization.--Autunite and torbernite usually are found in and near the intersections of diabase or basalt dikes with quartz pyrite veins. Both minerals coat fracture surfaces and project into small cavities in the fracture blocks. The fractures and cavities are also commonly iror stained. Locally, as in trench No. 2 (locality R-7, shaft No. 2) torbernite crystals are disseminated in the granite and coat altered grains of feldspar. Although autunite locally is most abundant near the surface, torbernite is predominant a few feet below the surface.

Size and grade. --The only uranium-bearing rock, on this claim, of economic importance under present conditions, lies within the ground explored by the Merry Widow mine. The measured uranium-bearing rock in the mine is defined vertically by the surface of the ground and the 130 -foot level, and horizontally by the eastern limits of the 40-,60-, and 130-foot levels and the western limits of the 40- and 130-foot levels. The highest-grade ore is within 20 feet of the shaft between the 60 -foot level and the surface. The size and grade of uranium deposits on the Merry Widow claim exclusive of the mine are indicated in the following table. 
Table 1.m-Results of sampling. Merry Widow claim. White Signal district, Grant County, New Mexico

\begin{tabular}{|c|c|c|c|c|c|c|c|}
\hline $\begin{array}{l}\text { Locality } \\
\text { number }\end{array}$ & $\begin{array}{l}\text { Sample } \\
\text { number }\end{array}$ & Material & Type & $\begin{array}{l}\text { Length } \\
\text { (feet) }\end{array}$ & $\begin{array}{c}\mathrm{eU} \underline{1} / \\
\text { (percent) }\end{array}$ & $\begin{array}{c}\mathrm{U} \\
\text { (percent) }\end{array}$ & $\begin{array}{c}\mathrm{P}_{2} \mathrm{O}_{5} \\
\text { (percent }\end{array}$ \\
\hline \multicolumn{8}{|c|}{ Trench $\mathrm{N}_{\mathrm{g}} \cdot \mathrm{I}$} \\
\hline & HLB - 1-1 & Graníte & Channel & 2.7 & 0.004 & 8.002 & 0.13 \\
\hline & 2 & do. & do. & 2.9 & .004 & .001 & .13 \\
\hline & 3 & Quartz pyrite vein, 1 inch thick & Grab & $=-$ & .007 & .006 & .54 \\
\hline & 4 & Diabase & Channel & 2.0 & .002 & .001 & 2.61 \\
\hline & 5 & do. & do. & 2.5 & .002 & .001 & 2.69 \\
\hline & 6 & do. & do. & 2.5 & .002 & .001 & 2.60 \\
\hline & 7 & Latite & do. & 0.5 & .003 & .001 & 0.83 \\
\hline & 8 & Granite, altered & do. & 2.5 & .004 & .001 & .10 \\
\hline & 9 & do. & do。 & 2.5 & .004 & .001 & .20 \\
\hline & 10 & do. & do. & 1.5 & .006 & .003 & .09 \\
\hline \multirow[t]{14}{*}{$\mathbf{R}-11$} & 11 & Latite and quartz-pyrite vein & do. & 0.3 & .023 & .019 & .53 \\
\hline & 12 & Granite & do. & 1.5 & .008 & .004 & .10 \\
\hline & 13 & Granite, altered & do. & 1.5 & .005 & .003 & .10 \\
\hline & 14 & do. & do。 & 2.0 & .009 & .005 & .14 \\
\hline & 15 & Granite, iron-stained & do. & 2.0 & .005 & .003 & .06 \\
\hline & 16 & Quartz-pyrite vein, 3 inches thick & Grab & $\therefore-$ & .005 & .003 & .17 \\
\hline & 17 & Granite , iron-stained & Channe1 & 2.0 & .004 & .002 & .10 \\
\hline & 18 & Granite & do。 & 2.0 & .007 & .002 & .07 \\
\hline & 19 & Granite, iron-stained & do. & 2.5 & .003 & .002 & .07 \\
\hline & 20 & Quartz-pyrite vein, 20 inches thick & do. & 2.0 & .009 & .007 & .23 \\
\hline & 21 & Granite, altered & do. & 2.0 & .004 & .003 & .09 \\
\hline & 22 & do. & do. & 2.5 & .004 & .003 & .13 \\
\hline & 23 & do. & do. & 2.0 & .009 & .009 & .14 \\
\hline & ( 24 & Diabase, autunite & do & 1.7 & .100 & .11 & 1. 18 \\
\hline \multirow[t]{5}{*}{$R-9$} & $(25$ & do & do & 2.7 & .029 & .025 & 2.18 \\
\hline & 26 & Diabase & Channel & 3.0 & .005 & .004 & 1.79 \\
\hline & 27 & do. & do. & 2.0 & .010 & .009 & 1.65 \\
\hline & 28 & Granite & do. & 3.0 & .005 & .004 & 0.18 \\
\hline & 29 & do. & do. & 3,0 & .006 & .002 & .12 \\
\hline
\end{tabular}

Trench $\mathrm{No}_{2} 2$

$\begin{array}{rrl} & \text { HLB-2-30 } & \text { Granite, silicified } \\ & 31 & \text { do. } \\ & 32 & \text { Granite, altered } \\ 33 & \text { Diabase, altered } \\ 34 & \text { Diabase, iron-stained } \\ 35 & \text { do. } \\ 36 & \text { Diabase, altered } \\ 37 & \text { Granite, iron-stained } \\ 38 & \text { Granite, altered } \\ 39 & \text { Quartz-pyrite vein } \\ & 40 & \text { Granite }\end{array}$

$\begin{array}{crrrr}\text { Channel } & 3.0 & 0.011 & 0.005 & 0.08 \\ \text { do. } & 4.1 & .003 & .002 & .06 \\ \text { do. } & 3.0 & .008 & .005 & .14 \\ \text { do. } & 3.1 & .006 & .003 & .56 \\ \text { do. } & 2.5 & .013 & .015 & 1.42 \\ \text { do. } & 3.0 & .004 & .003 & 1.70 \\ \text { do. } & 3.0 & .006 & .003 & 1.62 \\ \text { do. } & 3.0 & .005 & .003 & 0.35 \\ \text { do. } & 2.5 & .005 & .002 & .04 \\ \text { do. } & 2.5 & .006 & .005 & .15 \\ \text { do. } & 3.3 & .006 & .004 & .11\end{array}$


Table 1。-Results of sampling. Merry Widow claim, White Signal district. Grant County, New Mexico--Continued

Locality Sample Length eU $1 / \quad$ U $\quad P_{2} \mathrm{O}_{5}$ number number Material Type (feet) (percent) (percent) (percent)

Trench No, 2-Continued

\begin{tabular}{|c|c|c|c|c|c|c|c|}
\hline & HLB - $2-41$ & Granite, torbernite & do. & 2.0 & 0.011 & 0.008 & 0.04 \\
\hline & 42 & Quartz-pyrite vein & do. & 3.0 & .008 & .005 & .10 \\
\hline & 43 & Granite & do. & 3.0 & .006 & .005 & .07 \\
\hline & 44 & do. & do. & 3.8 & .005 & .003 & .11 \\
\hline & 45 & do & do. & 2.6 & .004 & .002 & .09 \\
\hline & 46 & Granite & do. & 3.0 & .004 & .002 & .06 \\
\hline & 47 & Granite, iron-stained & do. & 6.5 & .006 & .007 & .15 \\
\hline & ( HLB $-6-48$ & Diabase, iron-stained & Channel & 3.0 & .016 & .010 & .97 \\
\hline$R-8$ & ( HLB-7-49 & Diabase, fault gouge & do. & 3.0 & .020 & .010 & .46 \\
\hline
\end{tabular}

Trench No 5

$\begin{array}{rc}\text { HLB-5-50 } & \text { Diabase } \\ 51 & \text { do. } \\ 52 & \text { Granite, altered } \\ 53 & \text { do. } \\ 54 & \text { Quartz-pyrite vein } \\ 55 & \text { Granite, altered } \\ 56 & \text { do. } \\ 57 & \text { do. } \\ 58 & \text { Granite } \\ 59 & \text { do. } \\ 60 & \text { Quartz-pyrite vein } \\ 61 & \text { Granite } \\ 62 & \text { Granite, altered } \\ 63 & \text { Granite }\end{array}$

$\begin{array}{ccccc}\text { Channel } & 3.0 & 0.005 & 0.004 & 1.72 \\ \text { do. } & 2.0 & .006 & .004 & 0.95 \\ \text { do. } & 3.0 & .005 & .002 & .08 \\ \text { do. } & 3.0 & .020 & .002 & .08 \\ \text { do. } & 1.3 & .002 & .002 & .07 \\ \text { do. } & 2.0 & .005 & .002 & .07 \\ \text { do. } & 1.7 & .008 & .003 & .06 \\ \text { do. } & 2.0 & .005 & .002 & .04 \\ \text { do. } & 2.0 & .004 & .001 & .08 \\ \text { do. } & 1.6 & .008 & .006 & .08 \\ \text { do. } & 1.0 & .014 & .010 & .13 \\ \text { do. } & 2.0 & .007 & .002 & .06 \\ \text { do. } & 2.0 & .005 & .002 & .04 \\ \text { do. } & 1.5 & .005 & .001 & .07\end{array}$

Trench No. 3

$\begin{array}{rlcrrrr}\text { HLB-3-64 } & \text { Granite } & \text { Chip } & 2.0 & 0.004 & 0.001 & 0.13 \\ 65 & \text { Granite, altered } & \text { do. } & 1.5 & .005 & .001 & .07 \\ 66 & \text { do. } & \text { Channel } & 2.5 & .005 & .004 & .22 \\ 67 & \text { Latite } & \text { do. } & 0.5 & .005 & .004 & .23 \\ 68 & \text { Diabase, iron-stained } & \text { do. } & 2.5 & .009 & .007 & 1.48 \\ 69 & \text { Diabase } & \text { Chip } & 30.0 & .006 & .005 & 2.54 \\ 70 & \text { do. } & \text { Channel } & 2.5 & .008 & .005 & 2.31 \\ 71 & \text { Granite, altered } & \text { do. } & 2.5 & .010 & .007 & 0.40 \\ 72 & \text { Quartz-pyrite vein, one-half } & \text { Grab } & -. . & .008 & .004 & .32 \\ 73 & \text { inch thick } & & & & .004 & .06 \\ 74 & \text { Granite, altered } & \text { Channel } & 2.5 & .004 & .002 & .06 \\ 75 & \text { Granite, altered } & \text { Chip } & 17.0 & .005 & .002 & .06 \\ 76 & \text { Latite } & \text { Chip } & 7.0 & .005 & .002 & .07 \\ 77 & \text { Granite } & \text { Channel } & 1.5 & .006 & .006 & .15 \\ & & \text { do. } & 3.0 & .004 & .002 & .13\end{array}$


Table 1. -Results of sampling. Merry Widow claim, White Signal district, Grant County, New Mexico--Continued

Locallty Sample number number
Material
Length eU $1 /$ $\quad \mathrm{U} \quad \mathrm{P}_{2} \mathrm{O}_{5}$ Type (feet) (percent) (percent) (percent)

Trench No. 3--Continued

\begin{tabular}{|c|c|c|c|c|c|c|c|}
\hline \multicolumn{2}{|c|}{ HLB $-3-78$} & Quartz-pyrite vein, 24 inches thick & do. & 2.0 & 0.003 & 0.001 & 0.15 \\
\hline & 79 & Granite & do. & 2.5 & .004 & .001 & .08 \\
\hline & 80 & Granite, altered & Chip & 13.0 & .005 & .002 & .11 \\
\hline & 81 & Granite & do. & 14.0 & .003 & .001 & .08 \\
\hline \multirow{2}{*}{$R-4$} & ( HLB-8- 82 & Latite & Channel & 1.5 & .017 & .020 & .41 \\
\hline & $(\quad 83$ & Diabase & do。 & 1. 7 & .012 & .015 & .59 \\
\hline$R-5$ & HLB-9- 84 & do。 & do. & 2.5 & .076 & .067 & .42 \\
\hline \multirow{2}{*}{$R-3$} & ( HLB-10-85 & Diabase, iron-stained & Chip & 2.9 & .010 & .006 & 2,09 \\
\hline & ( 86 & do. & Grab & $\ldots$ & .021 & .020 & 1.60 \\
\hline \multirow{5}{*}{$\mathbf{R}-2$} & 87 & Fault gouge & Channel & 2.5 & .010 & .006 & 0.26 \\
\hline & 88 & Diabase, altered & do. & 2.5 & .017 & .020 & .66 \\
\hline & 89 & Rhyolite fault breccia & do. & 3.0 & .005 & .003 & .08 \\
\hline & 90 & Quartz monzonite & Grab & --- & .003 & .001 & .47 \\
\hline & 91 & Granite & $\mathrm{do}_{\mathrm{a}}$ & $=--$ & .005 & .001 & .05 \\
\hline \multirow[t]{11}{*}{$R-1$} & 92 & Basalt & do. & -+ & .092 & .10 & 1.56 \\
\hline & 93 & Quartz monzonite & do. & -- & .002 & .001 & 0.45 \\
\hline & 94 & Granite & do. & -- & .005 & .001 & .02 \\
\hline & 95 & Basalt & do. & $\cdots$ & .007 & .003 & 1.14 \\
\hline & 96 & Rhyolite & do. & -- & .004 & .001 & 0.06 \\
\hline & HL B-11-97 & Granite & Channel & 3.0 & .005 & .001 & .08 \\
\hline & 98 & do. & Grab & -- & .004 & .001 & .05 \\
\hline & 99 & Quartz-pyrite vein & Channel & 2.5 & .004 & .004 & .58 \\
\hline & 100 & Diabase & do. & 2.5 & .005 & .001 & 2.51 \\
\hline & HLB - 12-101 & Diabase, torbernite & Channel & 2.0 & .87 & .092 & 1.69 \\
\hline & 102 & Diabase & do. & 2.0 & .039 & .034 & 2.11 \\
\hline$R-13($ & 103 & Diabase, torbernite & do. & 2.0 & .098 & .077 & 1.77 \\
\hline( & 104 & Diabase & do & 2,0 & .018 & .014 & 2.11 \\
\hline ( & 105 & Granite, torbernite & Grab & -- & .10 & .070 & 0.44 \\
\hline
\end{tabular}

Trench No. 4

$\begin{aligned} \text { HLB-4-106 } & \text { Granite, altered } \\ 107 & \text { Diabase, altered } \\ 108 & \text { Granite, and diabase } \\ 109 & \text { Granite, altered } \\ 110 & \text { Diabase, altered } \\ 111 & \text { Granite } \\ 112 & \text { Diabase } \\ 113 & \text { Granite } \\ 114 & \text { Quartz-monzonite } \\ 115 & \text { Granite } \\ 116 & \text { Diabase } \\ 117 & \text { Granite }\end{aligned}$

$\begin{array}{crrrr}\text { Chip } & 17.0 & 0.004 & 0.001 & 0.14 \\ \text { Channel } & 3.0 & .003 & .001 & .39 \\ \text { do. } & 1.0 & .002 & .001 & .27 \\ \text { Chip } & 4.5 & .004 & .001 & .10 \\ \text { do. } & 26.0 & .002 & .001 & .43 \\ \text { do. } & 29.0 & .005 & .001 & .08 \\ \text { do. } & 31.0 & .002 & .001 & 2.58 \\ \text { do. } & 77.0 & .006 & .001 & 0.04 \\ \text { do. } & 9.0 & .003 & .001 & .43 \\ \text { do. } & 26.0 & .004 & .001 & .13 \\ \text { do. } & 26.0 & .002 & .001 & 2.02 \\ \text { do. } & 33.0 & .006 & .001 & 0.03\end{array}$


Table 1.--Results of sampling, Merry Widow claim, White Signaldistrict, Grant County, New Mexico--Continued

\begin{tabular}{|c|c|c|c|c|c|c|c|}
\hline $\begin{array}{l}\text { Locality } \\
\text { number }\end{array}$ & $\begin{array}{l}\text { Sample } \\
\text { number }\end{array}$ & Material & Type & $\begin{array}{l}\text { Length } \\
\text { (feet) }\end{array}$ & $\begin{array}{c}\mathrm{eU} \underline{1} / \\
\text { (percent) }\end{array}$ & $\begin{array}{c}\mathrm{U} \\
\text { (percent) }\end{array}$ & $\begin{array}{c}\mathrm{P}_{2} \mathrm{O}_{5} \\
\text { (percen }\end{array}$ \\
\hline \multicolumn{8}{|c|}{ Trench No. 4--Continued } \\
\hline & HLB $-4-118$ & Quartz-pyrite vein & Channel & 6.0 & 0.003 & 0.001 & 0.10 \\
\hline & 119 & Granite & Chip & 18.0 & .000 & .001 & .03 \\
\hline & 120 & Quartz-pyrite vein and gouge & Channel & 0.5 & .005 & .002 & .19 \\
\hline & 121 & Granite & Chip & 18.0 & .005 & .001 & .06 \\
\hline & 122 & Latite & Channel & 2.0 & .010 & .008 & .28 \\
\hline & 123 & Granite & Chip & 9.0 & .005 & .003 & .03 \\
\hline & 124 & Latite & Channel & 4.0 & .005 & .004 & .30 \\
\hline & 125 & Granite & Chip & 37.0 & .004 & .001 & .07 \\
\hline & 126 & Latite & Channel & 6.0 & .007 & .007 & .31 \\
\hline & 127 & Granite & Chip & 17.0 & .001 & .001 & .08 \\
\hline & 128 & Latite & Channel & 5.0 & .001 & .001 & .32 \\
\hline & 129 & Granite & Chip & 24.0 & .001 & .001 & .05 \\
\hline & 130 & Latite & Channel & 4.0 & .008 & .008 & .36 \\
\hline & 131 & Granite and quartz-pyrite veins & Chip & 40.0 & .005 & .001 & .07 \\
\hline & 132 & do. & do. & 40.0 & .004 & .001 & .04 \\
\hline & ss -1 & Granite, torbernite & Selected & --- & .021 & .014 & .07 \\
\hline
\end{tabular}


Table 2。--Results of sampling 1/。 Merry Widow mine, White Signal district, Grant County, New Mexico

Distance

Sample from shaft Length

number (feet) (feet) Location and description

40-foot level (west)

\begin{tabular}{|c|c|c|c|c|}
\hline 6557 & 0 & 2.1 & Back - diabase $\underline{3} /$ with altered granite - torbernite & 0.67 \\
\hline 6558 & & 2.0 & Back - gouge and iron oxide & .04 \\
\hline 6559 & 5 & 3.1 & Back - special of 5 -inch contact zone - torbernite & .39 \\
\hline 6560 & & 2.8 & Back - gouge, diabase, granite, iron oxide breccia-torbernite & .34 \\
\hline 6561 & & 4.0 & Back - diabase, iron oxide, bismite, hyalite & .04 \\
\hline 6562 & & 2.0 & Back - diabase, bismite, hyalite & .08 \\
\hline 6563 & 10 & 3.5 & Back - blocky diabase & .03 \\
\hline 6564 & & 3.0 & Back - gouge, altered granite, iron oxide, torbernite & .38 \\
\hline 6565 & & 3.8 & Back - altered diabase, bismite, torbernite & .15 \\
\hline 6566 & 15 & 4.2 & High back - altered granite, iron oxide, gouge & .05 \\
\hline 6567 & 20 & 3. 7 & Back - altered diabase, iron oxide & .05 \\
\hline 6568 & & 5,0 & High back - gouge, iron oxide, altered granite, torbernite & .42 \\
\hline 6589 & 25 & 2.7 & High back - gouge, altered diabase, iron oxide & .06 \\
\hline 6570 & 30 & 3.5 & High back - gouge, altered diabase, iron oxide, torbernite & .11 \\
\hline 6571 & 35 & 2.9 & High back - altered diabase, gouge, iron oxide & .07 \\
\hline 6572 & 40 & 3.3 & High back - gouge, altered diabase, iron oxide & .06 \\
\hline 6573 & 45 & 1.9 & Back - altered diabase, disseminated torbernite & .08 \\
\hline 6574 & & 2.0 & Back - strong iron oxide, gouge, altered diabase & .06 \\
\hline 7500 & 50 & 0.8 & Back - altered granite & .03 \\
\hline 7501 & & 1.5 & Back - gouge, altered diabase & .14 \\
\hline 7502 & & 1.7 & Back - diabase, iron oxide & .03 \\
\hline 7503 & 55 & 1.6 & Back - altered granite, iron oxide & .05 \\
\hline 7504 & & 1.0 & Back - gouge, iron oxide, altered diabase & .03 \\
\hline 7505 & 60 & 1.7 & Back - altered granite, iron oxide & .03 \\
\hline 7506 & & 0.8 & Back - gouge, iron oxide & .04 \\
\hline 7507 & & 2.2 & North wall - perpendicular to diabase-granite contact, torbernite & .48 \\
\hline
\end{tabular}

1/Modified from Keith, S。B。(1945)。 Keith collected 15 samples from the 130 -foot level which ranged from 0.03 to 0.08 percent uranium.

2/Average of analysis of duplicate samples; made at Rifle, Colo, and Tonawanda, N. Y.

3/Keith did not recognize latite in the mine. Part of the diabase and much of the gouge in the table are probably altered latice. 
Table 2, - Results of sampling $1 /$. Merry Widow mine, White Signal district, Grant County, New Mexico--Continued

Distance

Sample from shaft Length number (feet) (feet)

Location and description

40-foot level (east)

$\begin{array}{llllr}7508 & 5 & 2.0 & \text { Back - altered granite, iron oxide, torbernite } & 0.43 \\ 7509 & & 2.1 & \text { Back - gouge, iron oxide } & .33 \\ 7510 & 10 & 1.2 & \text { Back - altered granite } & .03 \\ 7511 & & 1.3 & \text { Back - altered granite, disseminated torbernite } & .31 \\ 7512 & & 0.9 & \text { Back - gouge, altered diabase, strong torbernite } & .31 \\ 7513 & & 2.2 & \text { Back - altered diabase, gouge, torbernite } & 1.76 \\ 7514 & 15 & 0.7 & \text { Back - gouge, altered diabase } & 0.63 \\ 7515 & & 2.2 & \text { Back - altered granite, iron oxide, torbernite } & .05 \\ 7516 & & 1.0 & \text { Back - diabase } & .32 \\ 7517 & & 0.4 & \text { Back - altered diabase, gouge, strong torbernite } \\ 7518 & & 1.4 & \text { Back - altered diabase, iron oxide } & .21 \\ 7519 & 20 & 0.2 & \text { Back - gouge } & 1.90 \\ 7520 & & 2.4 & \text { Back - altered granite, iron oxide } & 0.06 \\ 7521 & & 1.5 & \text { Back - altered granite, iron oxide, disseminated torbernite } & .02 \\ 7522 & & 2.2 & \text { Back - altered diabase } & .04 \\ 7523 & & 2.3 & \text { Back - altered diabase, iron oxide } & .04 \\ 7529 & 25 & 2.2 & \text { Back - altered granite, iron oxide stringers } \\ 7530 & 30 & 3.3 & \text { Back - altered granite, gouge - iron oxide stringers } & .34 \\ 7524 & 25 & 3.4 & \text { Back - granite, iron oxide stringers } & .05 \\ 7525 & & 0.9 & \text { Back - altered diabase } & .04 \\ 7526 & 37 & 3.5 & \text { East wall - altered granite, iron oxide stringers } & .01 \\ 7527 & & 3.3 & \text { East wall - altered granite, iron oxide stringers } & .02 \\ 7528 & & 3.1 & \text { East wall - altered granite, iron oxide - gouge vein } & .02 \\ 7531 & 25 & 1.2 & \text { North wall - altered granite, torbernite } & .04 \\ 7532 & & 0.7 & \text { North wall - altered diabase, torbernite } & .03 \\ & & & \end{array}$

60-foot level (west)

$\begin{array}{lcllr}6250 & 0 & 1.3 & \text { Back - altered diabase, torbernite } & 0.12 \\ 6251 & & 2.7 & \text { Back - gouge, iron oxide } & .03 \\ 6252 & & 1.4 & \text { Back - gouge, iron oxide, weak torbernite } \\ 6253 & 5 & 1.7 & \text { Back - brecciated diabase, gouge, torbernite } & .05 \\ 6254 & & 1.8 & \text { Back - gouge, iron oxide, torbernite } & .40 \\ 6255 & 10 & 3.7 & \text { Back - gouge, iron oxide, torbernite } & .52 \\ 6256 & 15 & 1.5 & \text { Back - gouge, iron oxide, torbernite } & .83 \\ 6257 & & 2.5 & \text { Back - iron oxide, gouge, bismite, torbernite } & .92 \\ 6258 & 20 & 5.0 & \text { Back - south cross-cut - altered granite, iron oxide } & .51 \\ 6259 & & 2.8 & \text { Back - gouge, iron oxide } & .03\end{array}$


Table 2.--Results of sampling 1/. Merry Widow mine, White Signal district,

Grant County, New Mexico--Continued

Distance

Sample from shaft Length

number (feet) (feet) Location and description

$\mathrm{U}_{3} \mathrm{O}_{8} \underline{2} /$

(percent)

\section{0-foot level (west)-Continued}

\begin{tabular}{|c|c|c|c|c|}
\hline \multicolumn{2}{|l|}{$\begin{array}{l}6260 \\
6261\end{array}$} & \multirow{2}{*}{$\begin{array}{l}3.5 \\
4.8\end{array}$} & \multicolumn{2}{|l|}{ Back - iron oxide, gouge, torbernite } \\
\hline 6261 & & & $\begin{array}{l}\text { East wall of north cross-cut - diabase, -pyrite - iron oxide - } \\
\text { bismite stringers }\end{array}$ & \\
\hline 6262 & & 4.8 & $\begin{array}{l}\text { East wall of north cross-cut - diabase, pyrite - iron oxide - } \\
\text { bismite stringers }\end{array}$ & \\
\hline 6263 & 25 & 0.3 & Back - granite, iron oxide & 0.04 \\
\hline 6264 & & 1.1 & Back = gouge, torbernite, hyalite & .12 \\
\hline 6265 & & 0.5 & Back - iron oxide, gouge, torbernite, hyalite & .11 \\
\hline 6266 & & 0.5 & Back - diabase, torbernite & .49 \\
\hline 6267 & 30 & 1,7 & Back - granite, iron oxide & .05 \\
\hline 6268 & & 1,3 & Back - gouge, iron oxide & .04 \\
\hline 6269 & & 0.5 & Back - diabase & .06 \\
\hline 6270 & 35 & 2.7 & East side raise -12.5 feet above rail - gouge, iron oxide torbernite & .13 \\
\hline 6271 & 40 & 1.7 & West side raise - 12,6 feet above rail - gouge, iron oxide & .08 \\
\hline 6272 & 45 & 0.8 & Back - gouge, torbernite & .26 \\
\hline 6273 & & 1.1 & Back - diabase & .12 \\
\hline 6274 & & 2,6 & Back - aliered granite & .02 \\
\hline 6275 & 50 & 0.9 & Back - altered granite, iron oxide & .06 \\
\hline 6276 & & 1.6 & Back - gouge, iron oxide, brecciated diabase & .03 \\
\hline 6277 & & 2.6 & Back - altered granite & .01 \\
\hline 6278 & 55 & 2.2 & Back - gouge, iron oxide & .02 \\
\hline 6279 & & t. 7 & Back - granite & .01 \\
\hline 6280 & 60 & 3,3 & Back - gouge, iron oxide & .02 \\
\hline 6281 & 65 & 2,5 & Back - brecciated granite, iron oxide, gouge & .02 \\
\hline 6282 & & 1.8 & Back - gouge, altered granite & .02 \\
\hline 6283 & 70 & 1.7 & High back - gouge, iron oxide & .04 \\
\hline 6284 & 75 & 1.3 & High back - gouge, diabase, granite & .03 \\
\hline 6285 & 80 & 1.7 & Back - granite, iron oxide & .02 \\
\hline 6286 & & 1.7 & Back - altered diabase, gouge, iron oxide & .07 \\
\hline 6287 & 85 & 2.2 & Back - granite & .04 \\
\hline 6288 & & 1.6 & Back - altered diabase, gouge, torbernite & .20 \\
\hline 6289 & 90 & 3.1 & Back - granite, hyalite & .04 \\
\hline 6290 & & 0.7 & Back - gouge, altered diabase, iron oxide, torbernite & .26 \\
\hline 6291 & 95 & 2.2 & Back - granite & .02 \\
\hline 6292 & & 1.1 & Back - altered diabase, gouge & .11 \\
\hline 6293 & 100 & 1.0 & Back - granite, iron oxide & .02 \\
\hline 6294 & & 1.0 & Back - altered diabase & .10 \\
\hline 6295 & & 1,2 & Back - iron oxide, gouge & .07 \\
\hline 6296 & 105 & 2.5 & Back - granite, iron oxide & .03 \\
\hline 6297 & & 1.8 & Back = granite, iron oxide & .03 \\
\hline
\end{tabular}


Table 2,--Results of sampling 1/. Merry Widow mine, White Signal district, Grant County, New Mexico--Continued

Distance

Sample from shaft Length

number (feet) (feet) Location and description

60-foot level (west)--Continued

$\begin{array}{llllr}6298 & 110 . & 0.9 & \text { Back - granite, iron oxide } & 0.03 \\ 6299 & & 0.7 & \text { Back - altered diabase, gouge } \\ 6300 & & 2.6 & \text { Back - granite, iron oxide } & .03 \\ 6301 & & 0.6 & \text { Back - altered diabase, gouge } & .03 \\ 6302 & 115 & 0.9 & \text { Back - altered granite, iron oxide } \\ 6303 & & 0.4 & \text { Back - altered diabase, torbernite } & .22 \\ 6304 & & 2.5 & \text { Back - altered granite, iron oxide } & .03 \\ 6305 & & 0.5 & \text { Back - gouge, altered diabase, iron oxide } & .32 \\ 6306 & 120 & 0.6 & \text { Back - altered diabase, gouge, torbernite } & .03 \\ 6307 & & 2.7 & \text { Back - granite, iron oxide } & .30 \\ 6308 & 125 & 0.7 & \text { Back - altered diabase, gouge } & .29 \\ 6309 & & 1.1 & \text { Back - granite, iron oxide, gouge } \\ 6310 & 130 & 0.8 & \text { Back - diabase, gouge, torbernite } & .03 \\ 6311 & & 1.9 & \text { Back - granite, iron oxide } & .15 \\ 6312 & 135 & 0.6 & \text { Back - gouge, diabase, iron oxide, torbernite } & .03 \\ 6313 & & 2.0 & \text { Back - granite, iron oxide } & .13 \\ 6314 & 140 & 0.6 & \text { Back - gouge, iron oxide } & .02 \\ 6315 & & 1.0 & \text { Back - iron oxide } & .11 \\ 6316 & & 2.3 & \text { Back - granite, iron oxide } & .02 \\ & & & \end{array}$

60 -foot level (east)

\begin{tabular}{|c|c|c|c|c|}
\hline 6317 & 10 & 1.6 & Back - diabase & 0.08 \\
\hline 6318 & & 2.0 & Back - gouge, altered diabase, iron oxide & .05 \\
\hline 6319 & & 1.5 & Back - diabase & .06 \\
\hline 6320 & 15 & 1,8 & $\begin{array}{l}\text { West side raise, } 10.5 \text { feet above rail - gouge, altered diabase, } \\
\text { torbernite }\end{array}$ & .36 \\
\hline 6321 & & 1.2 & West side raise, 10.5 feet above rail - diabase & .10 \\
\hline 6322 & 15 & 3.7 & West wall of cross-cut - diabase, pyrite, bismite & .04 \\
\hline 6323 & & 4.3 & West wall of cross-cut - diabase, pyrite, bismite & .03 \\
\hline 6324 & & 1.7. & West wall of cross-cut - diabase, pyrite, bismite & .03 \\
\hline 6550 & 20 & 4. 7 & East wall cross-cut - gouge, brecciated diabase, torbernite & .24 \\
\hline 6551 & & 3.2 & East wall cross-cut - granite, iron oxide & .02 \\
\hline 6552 & & 2.1 & East wall cross-cut - granite, iron oxide diabase & .03 \\
\hline 6553 & 25 & 4.2 & Back - diabase, pyrite, iron oxide & .05 \\
\hline 6554 & 30 & 1.7 & North wall of raise - granite, diabase, torbernite & .21 \\
\hline 6555 & 35 & 1.7 & North wall of raise - torbernite, granite, diabase & .40 \\
\hline 6556 & 40 & 2.0 & North wall of drift - torbernite, granite, diabase & .12 \\
\hline
\end{tabular}


Table 3.--Radioactive samples from the Merry Widow claim, White Signal district

$\begin{aligned} & \text { Locality number } \\ & \text { (All numbers }\end{aligned}$
$\begin{aligned} & \text { Dimensions } \\ & \text { (feet) }\end{aligned}$

refer to fig。 2) Length Width

uivalent uranium

$\mathrm{P}_{2} \mathrm{O}_{5}$

Description

R 1

R 2

R 3

\section{1}

$0.05-.10$

\subsection{2}

$.010-.017$

$.010-.021$

.017

076

01 (?)

.011

$.016-.020$

$.029-.100$

.013

.023

-
$-\quad .000-2.06$

15

15

.018-0.87

$.007-.014$

$.01(?)$
1.56 Radioactive basalt dike, torbernite crystals coat fractures near surface. Rock has been impregnated with iron oxides and silica.

$0.26-0.66$ Altered diabase along a fault, scattered autunite crystals along fractures

1.60-2.09 Two exposures of iron-stained diabase 25 feet apart along fault, fracture surfaces are radioactive, no uranium minerals visible

0.41 Radioactive latite dike 2 feet wide. Radioactive zone 30 feet long, no uranium minerals are visible.

0.42 Fault block of radioactive diabase 3 feet wide, less than 30 feet long, fracture surfaces coated with radioactive hyalite, no uranium minerals visible

... Iron stained fracture, along fault zone in granite, no samples analyzed

0.04 Torbernite coating fractures in granite near Merry Widow vein zone

0.46-0.97 Iron stained, silicified diabase adjacent to a fault, and radioactive gouge from this fault

1. 18-2.18 Fracture zone in a diabase dike between 2 fault veins. Fractures contain autunite, most abundantly near granite contact

1.42 Fractured, iron-stained diabase dike. No uranium minerals are visible。

0.53 Two and one-half inch quartz pyrite vein and adjacent latite dike. Vein is only locally uraniferous, No uranium minerals were observed.

-.- Merry Widow mine. See table 2 for sample analyses. Torbernite is largely concentrated along fractures in granite, diabase and latite near the shaft on the 40 and 60 -foot levels.

0.44-2.11 Fracture zone in granite and diabase. Torbernite coats fractures most abundantly near the contact on the diabase side.

04- 13 Two inch quartz pyrite vein and adjacent argylized granite wall rock。 No uranium minerals were observed。

-.. Narrow quartz vein and associated fracture zone in diabase dike. No samples were analyzed. 
Origin. --Although only secondary uranium minerals have been found in the White Signal district, observations made during this examination suggest that some of the quartz-pyrite veins may contain primary uranium minerals below the zone of oxidation.

The relatively unaltered rocks on the Merry Widow claim commonly have a lower uranium content than the material in quartz-pyrite veins. The large quartz-pyrite vein near the west end of trench no. 1 (fig.4) contains 0.007 percent uranium, whereas the wall rocks on either side contain 0,003 and 0.002 percent. A narrow quartz-pyrite vein along the contact between granite and diabase in the east end of trench no. 1 contains 0.006 percent uranium, whereas the adjacent granite and diabase contain only 0.001 percent. Similar examples are present in the other trenches suggesting that the quartz-pyrite veins have played an important part at least in the distribution of secondary uranium minerals.

During exploration of the Merry Widow vein by diamond drilling it was found that the vein material in the larger veins had been thoroughly oxidized by circulating meteoric waters to a depth of at least 550 feet. Pitchblende or other primary uranium minerals would probably be unstable in the highly acid waters produced by the oxidation of pyrite so that the lack of recognizable primary uranium minerals in the drill core merely suggests that if these minerals were once present they have since been removed. It is believed that the unoxidized parts of some of the veins may contain primary uranium minerals and that the distribution of secondary uranium minerals in altered rocks has resulted from precipitation of uranium from solution in meteoric waters along fractures in the more favorable host rocks,

There is a possible relationship between the latite (?) dikes and the uranium deposits. Locally, in the Merry Widow mine, the uranium minerals occur in fractures in the latite (?) away from the diabase dikes. At localities R-4 and R-11 (fig. 2) the uranium is closely associated with the latite (?). Field relationships suggest that the vein minerals were deposited after the intrusion of the latite (?) and before the intrusion of the rhyolite. Perhaps the mineral-bearing solutions followed closely after the intrusion of the latite (?), and the primary ore-bearing solutions may have been derived from the magma that consolidated to form latite (?).

Apparently the intermediate and basic rocks have been more fayorable hosts for the deposition of secondary uranium minerals than have the acid rocks. The reason for this is not entirely clear but may be due in part to the phosphate content. Certainly, it would seem that a high phosphate content in the host 
rock would be more conducive to precipitation of phosphate-bearing uranium minerals than would a low phosphate content. Of 19 samples that contained over 0.01 percent uranium, all but 2 contained over 0.30 percent $\mathrm{P}_{2} \mathrm{O}_{5}$. The average $\mathrm{P}_{2} \mathrm{O}_{5}$ content of these samples was 1.07 percent.

Description of deposits, --At 15 localities on or adjoining the Merry Widow claim, samples that contained over 0,01 percent uranium were obtained (table 3). All locality numbers refer to map (fig. 2).

\section{Results of exploration}

Five prospect trenches on the Merry Widow claim were carefully sampled and the samples analyzed for both uranium and phosphate (table 1) in order to determine the relative distribution of these elements in the different types of rocks and veins. The core of a diamond-drill hole, which collared 380 feet south of the main shaft and cut the vein at a depth of about $520 \mathrm{feet}$, was logged geologically at the drill site and also scanned radiometrically, both with a Geiger counter in the field and with a radiometric core scanner in the laboratory of the U. S. Geological Survey at Grand Junction, Colo. (fig. 6).

Trenching. - -The five prospect trenches on the Merry Widow claim were sampled in detail (fig. 3); and both abnormally radioactive rocks and relatively unaltered rocks outside the trenches were also sampled. The uranium content of 133 samples ranged from 0,001 to 0.11 percent (table 1 )。 Of these, 19 samples from 12 different localities contained more than 0.01 percent uranium. Results of the sampling suggest that the average uranium content of all rocks on the Merry Widow claim, where relatively unaffected by alteration other than weathering, was 0.003 percent or less. The phosphate content, on the other hand, varies widely .

in the different types of rock. The average $\mathrm{P}_{2} \mathrm{O}_{5}$ content of rocks on the Merry Widow claim is: diabase 1.60 percent; basalt 1.35 percent; latite 0.37 percent; quartz monzonite porphyry 0.45 percent; granite 0.10 percent; rhyolite 0.06 percent, Of 19 samples that contained over 0.01 percent uranium, only two contained less than 0.30 percent $\mathrm{P}_{2} \mathrm{O}_{5}$. These were also the only samples taken more than 2 feet from diabase, basalt, or latite.

Diamond drilling.--In May 1950 the owner of the Merry Widow claim explored the vein by a diamond-drill hole which collared 380 feet south of the Merry Widow shaft. The hole was drilled with an AX bit on a bearing of $N_{0} 60^{\circ} E_{0}$, at minus $72^{\circ}$ and was intended to intersect the vein at a depth of about 575 feet. The hole cut the vein between 520 and 550 feet and was bottomed at 650 feet. The overall core 
recovery was 79.6 percent, For the most part the core is medium-grained granite composed of quartz ( 30 percent), potash feldspar ( 60 percent), and biotite--and other mafic minerals--(10 percent)。Feldspars are moderately kaolinized to a depth of 200 feet. From 200 to 550 feet the feldspars are weakly kaolinized and some of the grains are soft and greenish. Near the veins the feldspars are moderately sericitized. The granite from 550 to 650 feet is unaltered.

The core from 72 to 97 feet consists of diabase from a dike, fine-grained near the contacts, and medium- to coarse-grained in the center. The diabase is highly fractured and plagioclase has been altered to clay. Mafic minerals give the rock a characteristic dull greenish-gray color.

The core contains many quartz-pyrite veins, most of which are less than one-half inch thick although a few are between one-half and two inches thick. The veins are abundant but show no persistent orientation. They are completely oxidized to a depth of 80 feet and partly oxidized to a depth of 150 feet. Below 150 feet pyrite is oxidized only in the wider vein zones. In the Merry Widow vein zone between 520 and 550 feet, the pyrite in the veins is oxidized to limonite; the wall rock is intensely altered and stained, A two-inch vein of massive limonite at 528 feet and two one-inch quartz veins at 540 feet are the largest individual veins in this zone. The latite (?) dike locally parallel with the vein in the Merry Widow mine was not recognized in the core. Many quartz-specularite veinlets are present between 380 and 650 feet. The wall rock along the border of these veins is only slightly iron stained.

In the field, the unshielded probe of a Geiger counter was held in contact with the core and the minimum and maximum meter reading during a 30 -second period was recorded. All readings were on the 0.2 scale and background for the granite was 1 to 6 scale divisions.

Abnormally radioactive zones in the core are commonly restricted to narrow fractures less than oneeight inch thick. Crystals of torbernite were noted in some of the fractures at depths of $127,151,154,156$, 161 , and 184 feet (fig。 6 ). Other radioactive fracture surfaces showing no torbernite, at $80,170,214,229$, $239,246,278,324,510,540$, and 542 feet, were usually coated with fine-grained dark green and white minerals, possibly a mixture of talc and serpentine.

In the Merry Widow vein zone at 540 feet, two weakly radioactive quartz veins 1 inch thick gave readings of 6 to 12 scale divisions. Two feet below these veins, a fracture filled with amorphous dark green 
US DEPARTMENT OF THE INTERIOR

38 GEOLOGICAL SURVEY

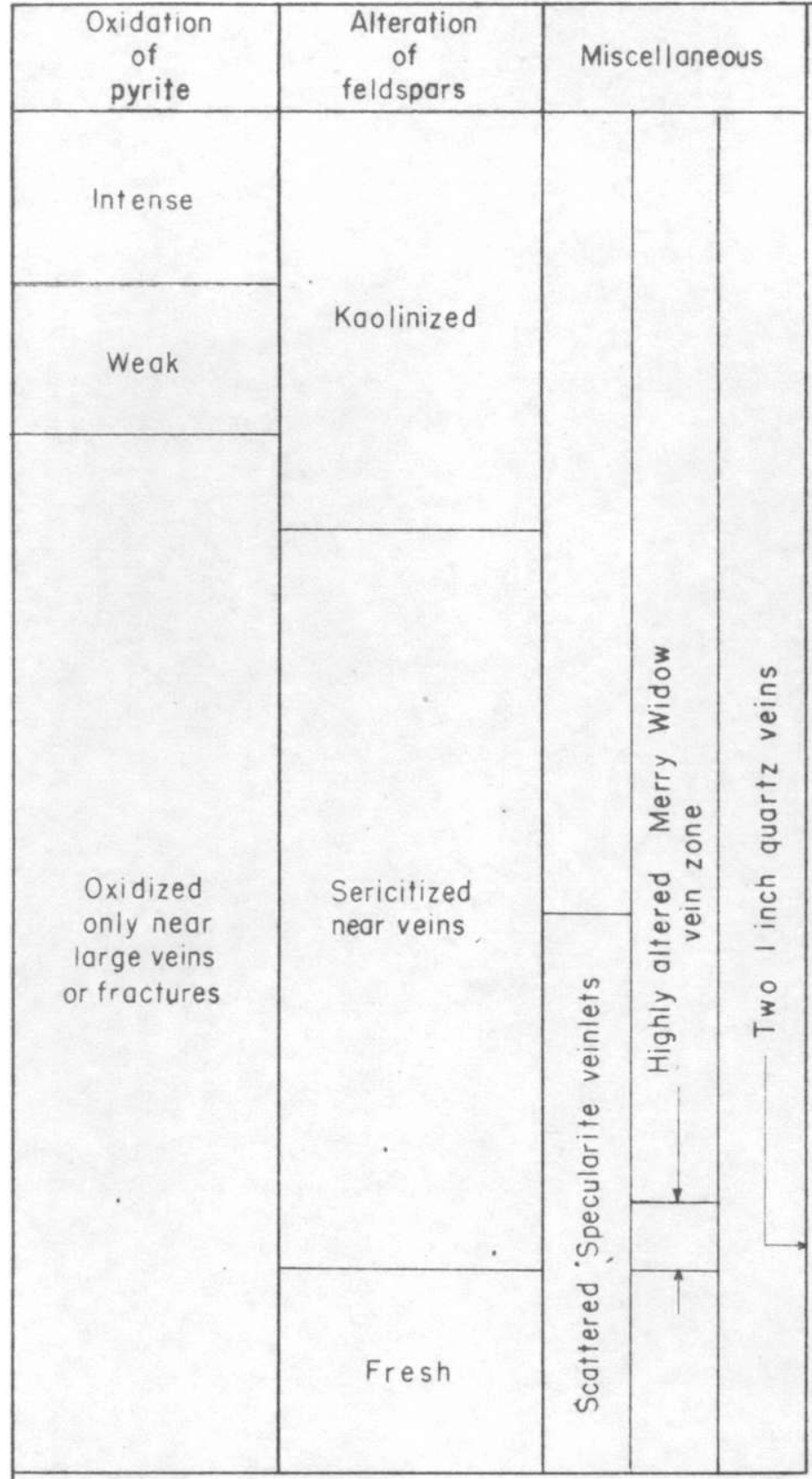

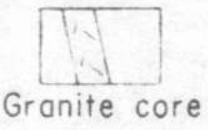

$\left[\begin{array}{l}+ \\ x\end{array}\right]$

Diabase core

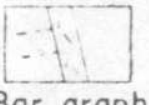

Bor graph showing radioactivity (field)

Torbernite in

fractures

$2010 \quad 0$

Average rate meter reading
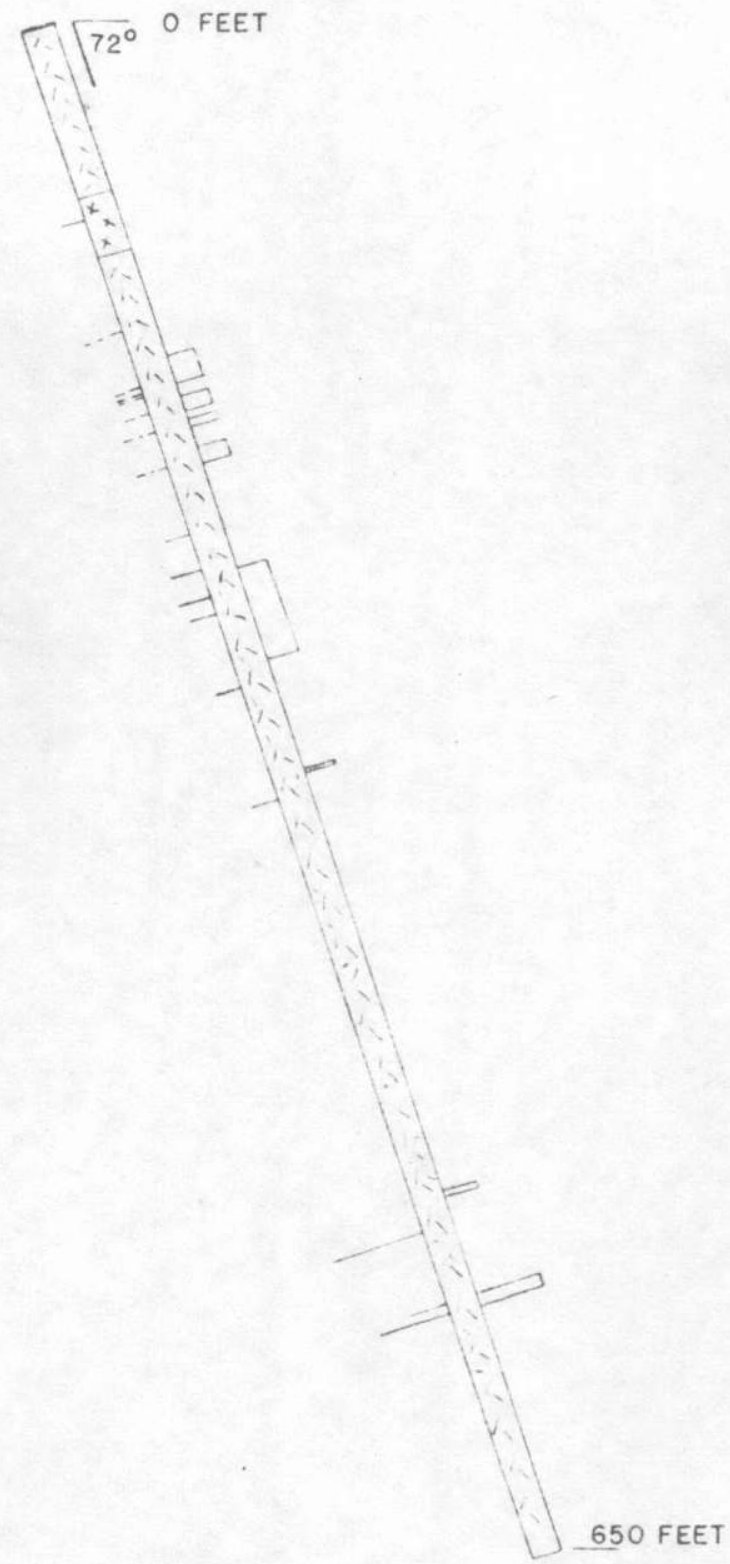

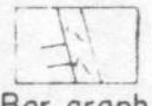

Bor graph showing radioactivity

(field)

no identifiable

minerals

$2010 \quad 0$

Average rate meter reading

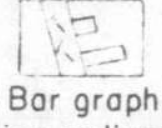

showing radioactivity

(core sconner) 
and black minerals gave readings of 12 to 17 scale divisions. Similar black radioactive material was noted at 2.78 feet and 510 feet but no uranium minerals have been identified at these places. Specimens of these black fracture fillings from 278,510 , and 542 feet were analyzed radiometrically in Denver and found to contain 0.2 to 0.3 percent equivalent uranium. The granite adjacent to the fractures had an equivalent uranium content of 0.01 to 0.02 percent.

The results of the core scanning in Grand Junction cannot be converted to equivalent uranium content because the scanning machine is calibrated to measure radioactivity of sedimentary rocks. The assumption was made, however, that the normal or background radioactivity for the rock is 380 counts per minute. On this basis, most of the core is barren. Seven narrow zones have radioactivity less than 150 counts per minute above the background and are designated as very low grade。One zone from 540 to 546 feet gave 158 to 384 counts per minute above the background and was called low grade. This zone is in the Merry Widow vein (fig。 6) and includes two 1-inch quartz stringers and a dark-colored fracture filling.

\section{Suggestions for prospecting}

Secondary uranium minerals on the Merry Widow claim have been found most commonly within the strong, easterly-trending Merry Widow vein zone where this zone cuts mafic or intermediate dikes, high in phosphate. Prospecting for these minerals should, therefore, be concentrated on the intersections of quartzpyrite veins, such as the Merry Widow vein, with these dikes. Any search for primary uranium minerals should be guided by the same principles of ore control that govern the localization of the primary base-metal sulfides in the area.

\section{Reserves}

The only uranium-bearing rock known to occur on the property in sufficient quantity and of sufficient grade to constitute ore reserves, under market conditions existing in 1952, lies close to the Merry Widow shaft within the Merry Widow vein zone between the 60 -foot level and the surface. 
The Apache Trail uranium prospect in sec, 2, $T_{0} 20 \mathrm{~S}_{0}, \mathrm{R}_{0} 15 \mathrm{~W}$, White Signal district, Grant County, N. Mex (fig. 1) is an unpatented claim in a school section. It is leased from the state by Mr. Charles $N_{0}$ Russell, Box 8, Tyrone, N. Mex。, and Mrs。 Elsie R。 Wiley, 1451 South Oakhurst Drive, Los Angeles 35, Calif The claim is accessible by vehicle according to the following directions: go 2.4 miles north from White Signal, N. Mex $;$ turn left (west) at gate onto an ungraded road; follow road for 2 miles to the Apache Trail prospect.

The claim was originally located for copper about 1890 , but the ore production is unknown. Five cars of copper carbonate ore, averaging 5 percent copper and 5 ounees of silver per ton, were shipped between 1915 and 1920 。

The original claim was abandoned and the present claim was located for gold in 1927. Bismuth, a common associate of gold in the district, was recognized at pit No, 5 (fig. 7 ) in a quartz-hematite vein, and 50 tons of ore, averaging 1-1/2 ounces gold per ton, and 4 percent bismuth, was shipped, Bismuth in the ore is said to hinder both concentration and smelting of other metals.

A 200-foot vertical shaft was sunk and 265 feet of drifts and cross cuts on the 100-foot level were driven in 1932. The bismuth-gold vein was never found in these workings. The shaft is inaccessible below the 100-foot level. Prospect pits have been dug at several places along the hematite vein (fig. 7).

$H_{\circ} L_{a}$ Bauer, $r_{\text {。 }}$ mapped, sampled and radiometrically examined the ground surface (fig. 7 ), and the 100-foot level (fig. 8) during part of three days in May 1950 。

\section{General geology}

The country rock in the vicinity of the Apache Trail claim is a medium-grained biotite granite of pre-Cambrian age. On the claim the granite is cut by a fine-grained diabase dike, 1 to 2 feet thick and a quartz-hematite vein 8 feet thick. The diabase dike is believed to be older than the vein because hematite appears to replace parts of the dike.

A greenish porphyritic dike, perhaps andesite porphyry, is exposed at the eastern end of the claim. The relation of this dike to the hematite vein and the diabase is not known. A well-defined fault zone is 
UNITED STATES DEPARTMENT OF THE INTERIOR

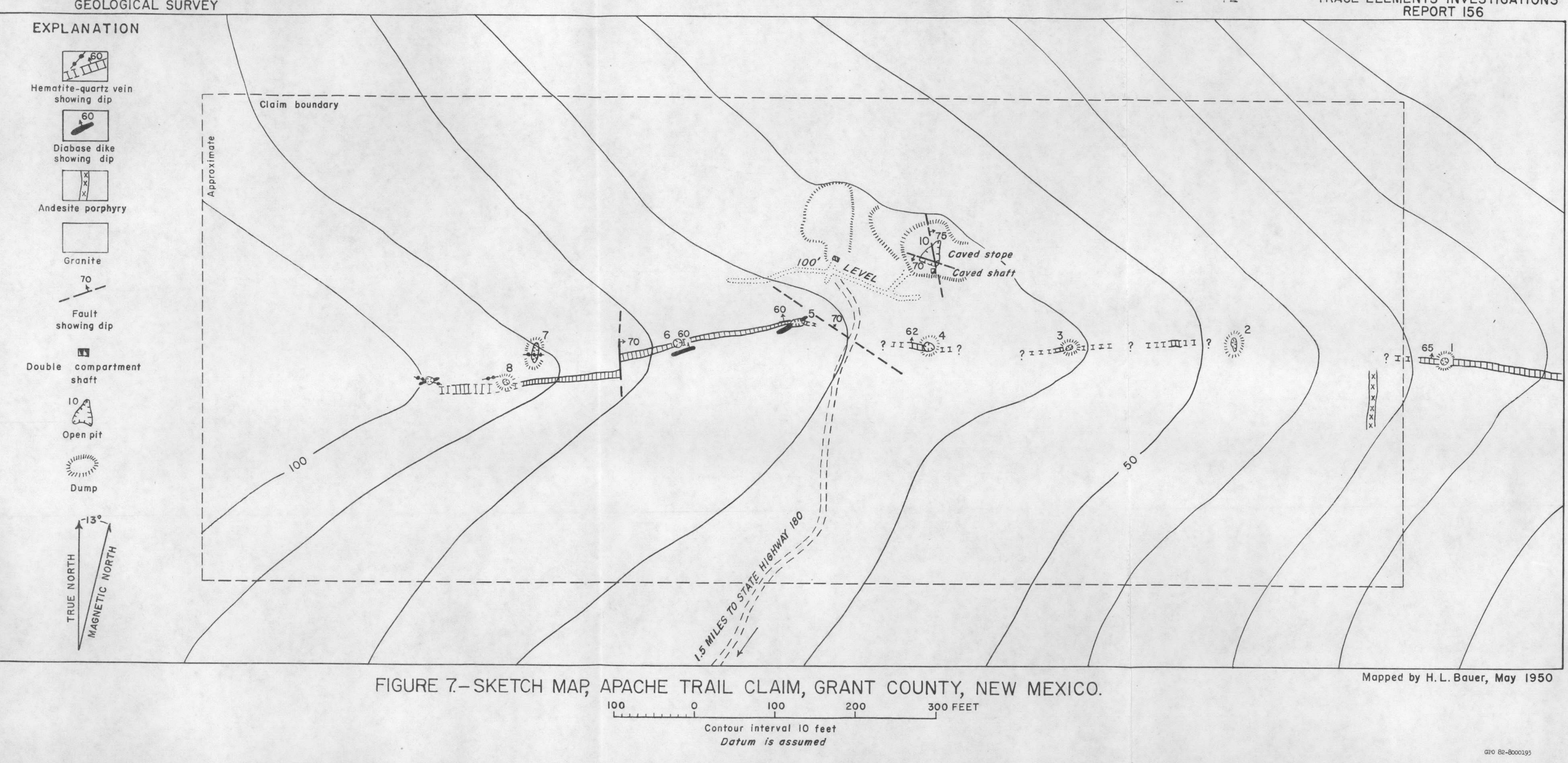




\section{$>$}

- 1.

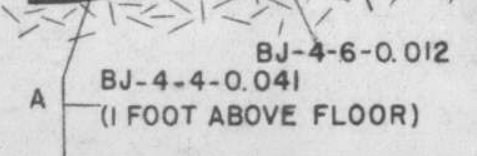

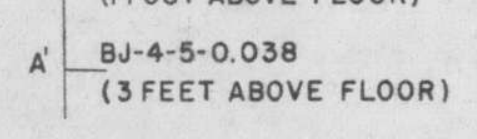
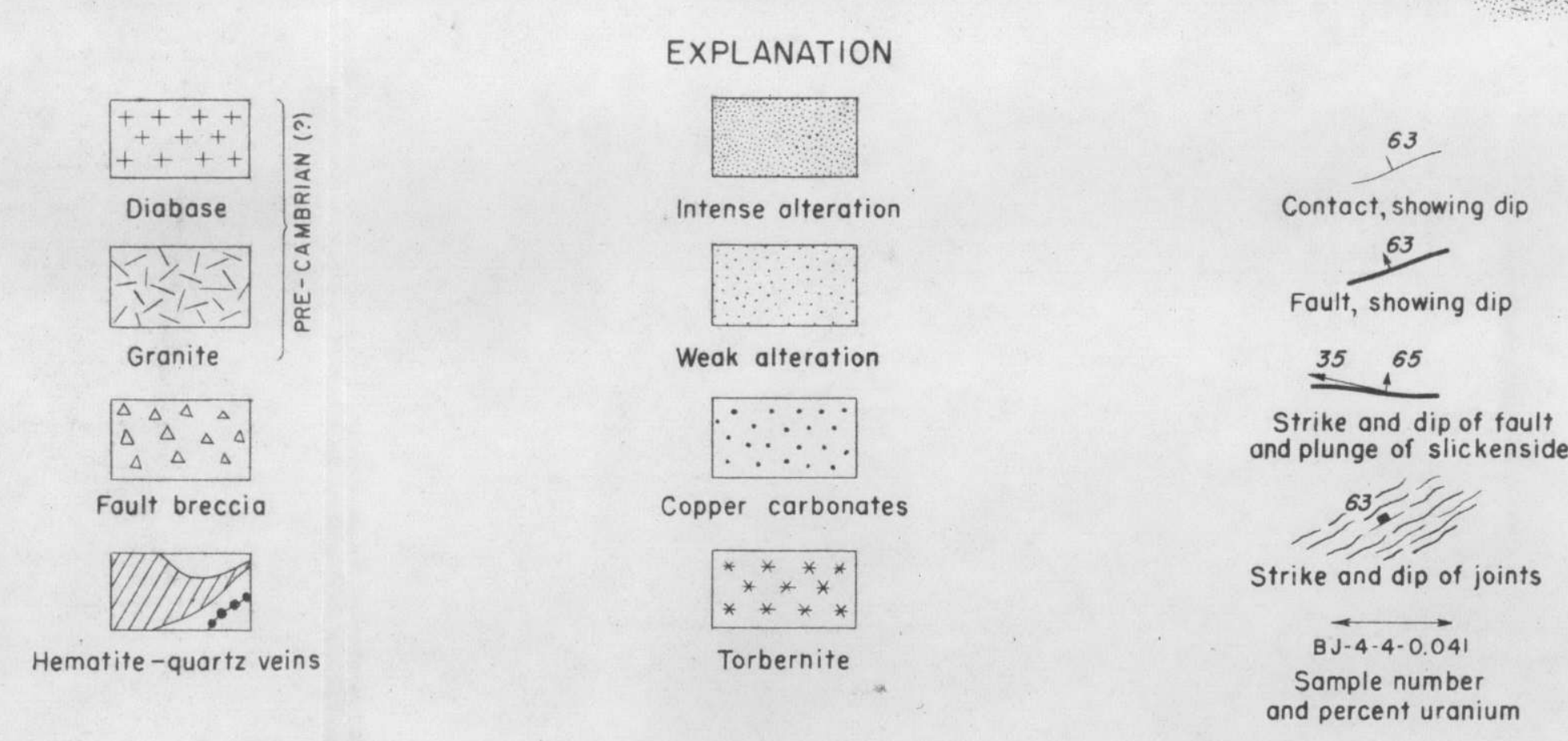

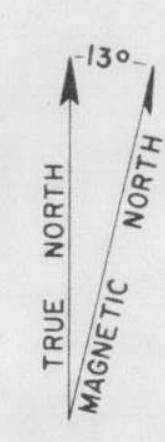

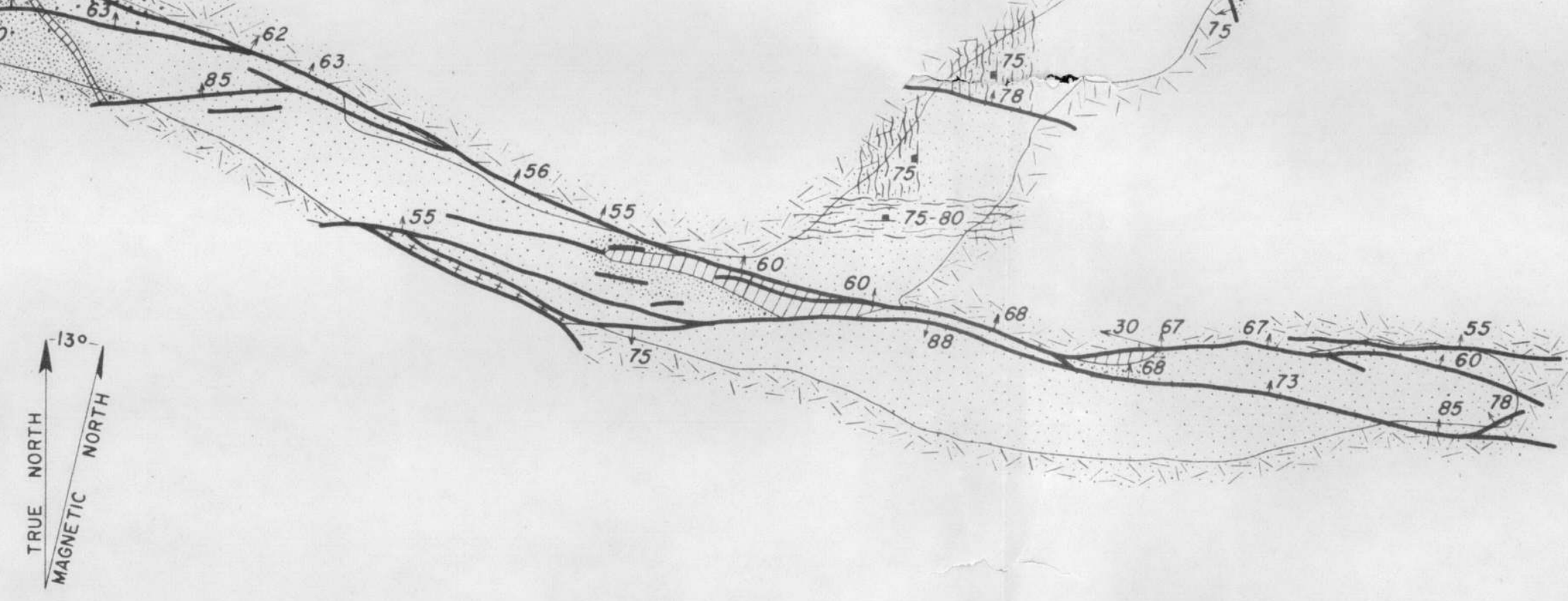


exposed in the east drift and in the easternmost 40 feet of the west drift on the 100 -foot level. Fragments of hematite in the fault zone indicate that this faulting is later than the vein. Fault gouge and slickensides occur on the hanging wall of the diabase dike on the 100-foot level; other faults are also present in the old copper stope (pit no, 10) and near pits nos, 5 and 6 。

The granite is fresh, except at the old copper stope (pit no, 10) and near the quartz-hematite vein, where it is altered to a soft fine-grained material for as much as 5 feet from the vein. Farther from the vein, the rock is less intensely altered and the original texture of the granite can be recognized. The diabase dike is altered and soft on the 100-foot level and in various pits on the surface.

\section{Radioactive deposits}

Two types of radioactive deposits occur on the Apache Trail claim. The larger deposit is the quartzhematite vein which does not contain visible uranium minerals; the other deposit is the diabase dike that locally contains visible torbernite.

The quartz-hematite vein is composed of specularite, magnetite, quartz, and a massive dull variety of hematite. Locally gold, copper-carbonate, limonite pseudomorphous after pyrite and lead and bismuth minerals are found in or adjacent to the quartz-hematite vein. The vein is up to 8 feet thick and locally pinches out; the average thickness is about 3-1/2 feet, it is resistant to weathering and can be traced for several thousand feet east and west of the Apache Trail claim. No uranium minerals were seen in the quartzhematite vein, although the rocks were radioactive at all places where sulfide minerals were originally present, and locally elsewhere Radiometric readings taken along the quartz-hematite vein at the surface and underground, range from two divisions on the 0.2 scale to five divisions on the 2.0 scale of a Geiger - Mueller counter with six-inch probe held one inch from the outcrop. Background readings on granite range from one to five divisions on the 0.2 scale. Radiometric readings in pit No, 1 range from 15 on the 0,2 scale to 5 on the 2.0 scale, and a 3-1/2 foot-channel sample cut across the quartz-hematite vein contains 0.012 percent uranium.

Radiometric readings along the hematite vein on the 100 -foot level range from 15 to 20 on the 0.2 scale and a 3-foot sample cut across the vein contains 0.011 percent uranium (table 3). 
The diabase dike is highly radioactive only at the western end of the 100-foot level where individual clusters of flat green square crystals of torbernite occur in fractures (fig. 8). Two samples across the diabase dike at this locality contain 0,041 and 0,038 percent uranium respectively. Two samples from diabase and altered granite in this vicinity contained 0.008 and 0.012 percent uranium respectively (table 4).

The small fault along the footwall of the diabase dike has been mineralized locally and torbernite crystals are concentrated next to this fault.

\section{Suggestions for prospecting}

The distribution of radioactive deposits on this claim suggests that concentrations of torbernite are apt to occur within the diabase dike where it is fractured or where it has been cut by faults and veins. Radioactivity of gossans along the quartz zein may indicate the presence of primary uranium minerals in this vein below the zone of oxidation.

Table 4.--Sample data, Apache Trail claim

\begin{tabular}{|c|c|c|c|c|c|c|c|}
\hline $\begin{array}{l}\text { Sample } \\
\text { number }\end{array}$ & Location & Material & $\begin{array}{l}\text { Equivalent } \\
\text { uranium } \\
\text { (percent) }\end{array}$ & $\begin{array}{l}\text { Uranium } \\
\text { (percent) }\end{array}$ & $\begin{array}{l}\text { Insoluble } \\
\text { residue } \\
\text { (percent) }\end{array}$ & $\begin{array}{c}\text { Iron } \\
\text { (percent) }\end{array}$ & $\begin{array}{l}\text { Copper } \\
\text { (percent) }\end{array}$ \\
\hline BJ $-4-4$ & $\begin{array}{l}100 \text {-foot level. } \\
\text { western face }\end{array}$ & Diabase, 3 feet thick & 0.033 & 0.041 & & & \\
\hline $4-5$ & do. & do. & .017 & .038 & & & \\
\hline $4-6$ & $\begin{array}{l}\text { 100-foot level, } \\
\text { western part }\end{array}$ & $\begin{array}{l}\text { Diabase and } \\
\text { altered granite }\end{array}$ & .011 & .012 & & & \\
\hline $4-7$ & do. & do. & .010 & .008 & & & \\
\hline $4-8$ & $\begin{array}{l}100 \text {-foot level, } \\
\text { western part }\end{array}$ & $\begin{array}{l}\text { Hematite-quartz vein, } \\
3 \text { feet thick }\end{array}$ & .013 & .011 & 12.44 & 58.67 & 1.36 \\
\hline $5-9$ & $\begin{array}{l}\text { Pit no. 1, } \\
\text { east end of claim }\end{array}$ & do. & .021 & .012 & 21.73 & 42.93 & 0.82 \\
\hline
\end{tabular}




$$
\text { Blue Jay claim }
$$

The Blue Jay claim is about 400 feet west of a dirt road which joins New Mexico Highway 180 at White Signal, about three-fourths of a mile north of the property (fig。 1)。 The quarter section corner of the boundary between secs, 23 and 26, $T, 20 S_{0}, R_{0} 15 W_{0}$, New Mexico principal meridian, lies within the claim boundaries. The claim was located in 1949 by Otto and Fred Prevost of White Signal and Silver City respectively, and is leased to $E_{0} B$, Killion of Silver City, $N_{0}$ Mex, Granger and Bauei examined the radioactive deposits on the Blue Jay claim in March 1950 and mapped the area containing radioactive deposits (fig. 9) by plane table on a scale of 1 inch equals 30 feet. Forty-four samples were taken; both radioactive and barren rocks were sampled and assayed for $\mathrm{P}_{2} \mathrm{O}_{5}$ as well as uranium. It is believed that the phosphate content of the country rock partly determined the localization of uranium minerals. The White Signal district had previously been examined by the Union Mines Development Corporation (Keith, 1944; 1945) but this examination did not include the Blue Jay claim.

Prior to the examination by Granger and Bauer, $\mathrm{Mr}_{\mathrm{o}}$ Killion had removed the overburden from four localities on the claim by bulldozer. These localities were selected by him on the basis of abnormal radioactivity detected with a portable Geiger counter. No ore has been produced.

\section{General geology}

The Blue Jay claim is underlain by a large mass of pre-Cambrian granite intruded by dikes of various compositions。

Granite $=$ The granite that forms the country rock in the vicinity of the Blue Jay claim is typically a leucocratic, biotite-poor, medium-grained rock in which the feldspars are partly argillized。

Diabase. - A diabase dike (fig, 9), faulted, and intruded by other rocks, trends northwest across the Blue Jay claim. Rock mapped as diabase in the northwestern bulldozer cut is intensely altered, friable, and locally bleached or iron stained. The diabase surrounding a 10-foot pit near the western margin of the area (fig。9) is bleached nearly white and cut by paper-thin veinlets containing specularite and siderite。 B a s a 1t, $=-$ A dark gray fine-grained dike about 7 feet wide, which is believed to be basait, strikes northwest nearly parailel to the diabase (fig.9). 


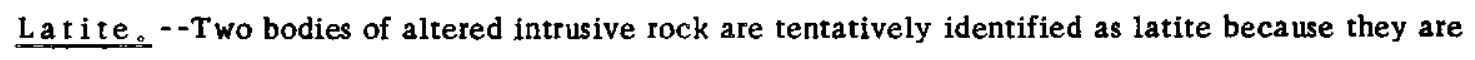
similar in habit and general appearance to unaltered latite outside the mapped area. These bodies have an easterly trend and are separated by rhyolite dikes. They may have originally been part of a more extensive dike or plug.

Aphanitic dikes - -A thoroughly fractured, friable, aphanitic dike about 3-1/2 feet wide is exposed in the northernmost bulldozer trench. It strikes about $N_{0} 80^{\circ} \mathbf{E}_{\circ}$ and dips vertically。 A 1- to 6-inch dike of similar material is exposed in a shallow pit 40 feet west of this trench. Minerals and texture of the original rock have been destroyed by intensive alteration。

Rhyolite - A large, white to gray rhyolite dike trends eastward across the area mapped and dips about $70^{\circ} \mathrm{S}$. Near the east edge of the area (fig,9) this dike contains four small inclusions of granite。

Yeins.--Most of the faults on the Blue Jay claim are occupied by dikes or veins. Where the faults are unmineralized they are obscured and display little brecciation or marginal fracturing Two types of veins occupy the faults: specularite veins and quartz-pyrite veins. A persistent specularite vein one-half to 2 inches wide trends about $\mathrm{N}_{\mathrm{o}} 70^{\circ} \mathrm{E}$. and dips steeply northward throughout a length of about 260 feet. Other minor specularite veins are short and very narrow.

Most of the veins are filled with limonite and quartz and are bordered by argillized, and less commonly, by sericitized wall rock. These are believed to be oxidized quartz-pyrite veins.

\section{Uranium deposits}

The uranium deposits on the Blue Jay claim are most commonly found in intermediate or basic dikes near oxidized quartz-pyrite veins, Two secondary uranium minerals have been found in the deposits. One is a tabular, green, non-fluorescent mineral, probably torbernite; the other is a yellow powdery mineral with weak yellow fluorescence, which was not identified. Torbernite coats fracture surfaces in the rock at sample localities HLB-15-137, $-159,-163,-170$, and -176 (fig。9). At sample locality HLB-15-177 the torbernite coats fracture surfaces in granite, and the contact between a quartz vein and argillized feldspar. The yellow secondary uranium mineral coats innumberable fracture surfaces in the larger aphanitic dike with a dull amorphous powder (fig。9). The prevalence of this mineral in the dike makes this rock the richest sampled (table 5)。 
Table 5。--Results of sampling, Blue Jay claim, White Signal district, Grant County. New Mexico

\begin{tabular}{|c|c|c|c|c|c|}
\hline $\begin{array}{l}\text { Sample } \\
\text { number 1/ } \\
\text { HLB-15 }\end{array}$ & Material & $\begin{array}{l}\text { Field meter } \\
\text { readings } 2 \text { / }\end{array}$ & $\begin{array}{l}\text { Equivalent } \\
\text { Uranium } \\
\text { (percent) }\end{array}$ & $\begin{array}{l}\text { Uranium } \\
\text { (percent) }\end{array}$ & $\begin{array}{c}\mathrm{P}_{2} \mathrm{O}_{5} \\
\text { (percent) }\end{array}$ \\
\hline & Fresh rock & 1 & & & \\
\hline 151 & Granite & & 0.004 & 0.001 & 0.36 \\
\hline 153 & do & & .001 & .001 & .43 \\
\hline 179 & do. & 2 to 7 & .004 & .002 & .65 \\
\hline 180 & do. & 0 to 5 & .004 & .001 & .60 \\
\hline 152 & Diabase & & .007 & .005 & 2.86 \\
\hline 154 & do. & & .003 & .001 & 2.95 \\
\hline 155 & do. & & .003 & .002 & 2.93 \\
\hline 141 & Basalt & 4 to 8 & .004 & .003 & 2.58 \\
\hline 150 & Rhyolite & & .003 & .001 & 0.48 \\
\hline 157 & do. & & .002 & .001 & .50 \\
\hline 143 & Granite and vein material & 13 to 16 & .020 & .013 & .35 \\
\hline 145 & do. & & .050 & .035 & .39 \\
\hline 148 & do. & & .020 & .010 & .43 \\
\hline \multicolumn{3}{|c|}{ Altered rock } & \multicolumn{2}{|c|}{ * } & \\
\hline 138 & Granite, altered & 12 to 20 & 0.014 & 0.009 & 0.37 \\
\hline 139 & do & 11 to 18 & .011 & .006 & .54 \\
\hline 140 & do. & 2 to 6 & .004 & .003 & .41 \\
\hline 142 & do. & 4 to 9 & .008 & .006 & .43 \\
\hline 144 & Granite, altered & 5 to 9 & .008 & .009 & .54 \\
\hline
\end{tabular}

1/Sample localities shown on figure 9

2/Readings in divisions on 2.0 scale of beta-gamma rate meter are underlined; others are readings on the 0.2 scale. 
Table 5。--Results of sampling. Blue Jay claim, White Signal district, Grant County, New Mexico--Continued

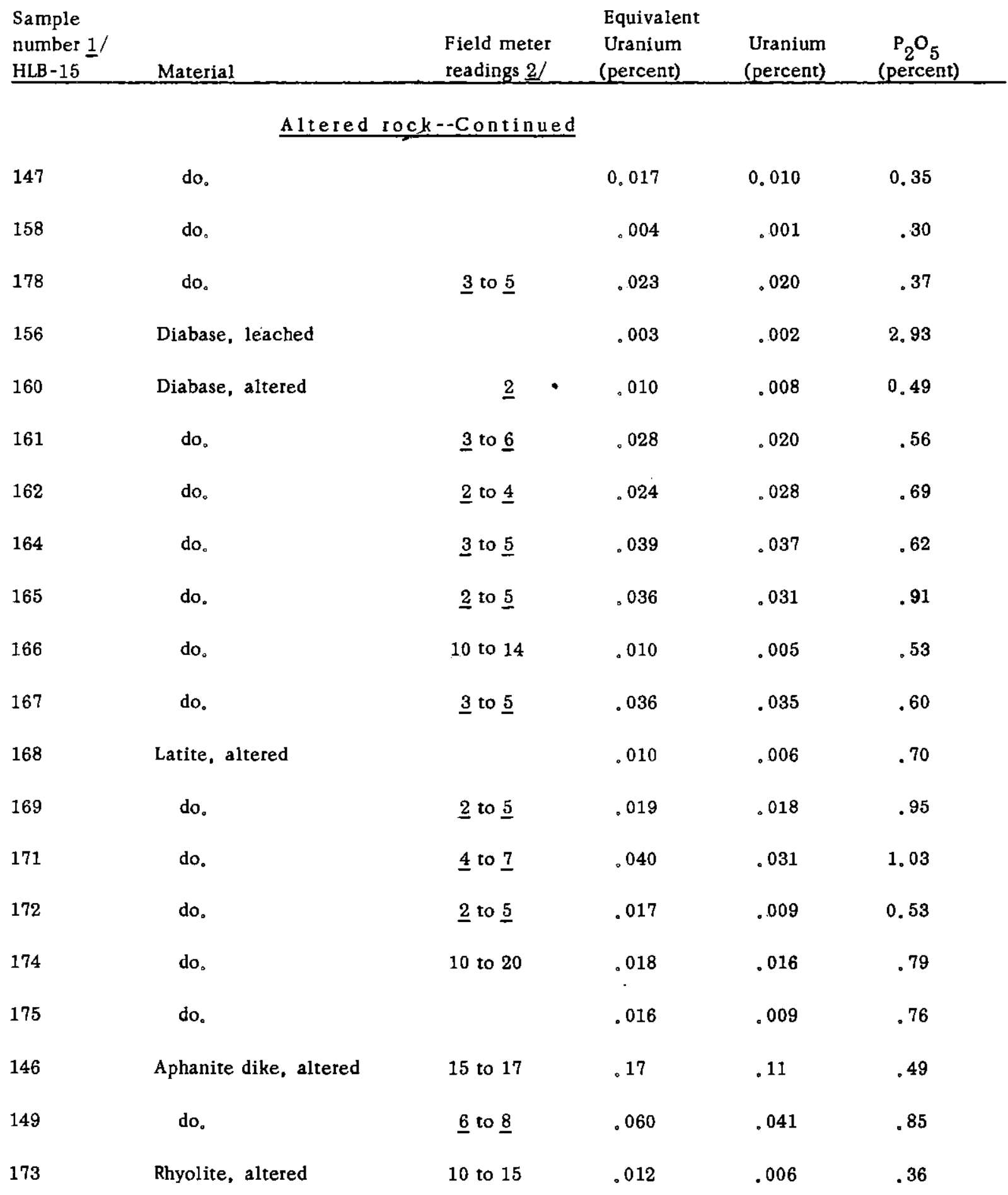


Table 5。--Results of sampling, Blue Jay claim, White Signal district, Grant County. New Mexico--Continued

\begin{tabular}{|c|c|c|c|c|c|}
\hline $\begin{array}{l}\text { Sample } \\
\text { number } 1 / \\
\text { HLB-15 }\end{array}$ & Material & $\begin{array}{l}\text { Field meter } \\
\text { readings } 2\end{array}$ & $\begin{array}{l}\text { Equivalent } \\
\text { Uranium } \\
\text { (percent) }\end{array}$ & $\begin{array}{l}\text { Uranium } \\
\text { (percent) }\end{array}$ & $\begin{array}{r}\mathrm{P}_{2} \mathrm{O} \\
\text { (perc }\end{array}$ \\
\hline \multicolumn{6}{|c|}{ Rock showing visible torbernite } \\
\hline 177 & Granite, visible torbernite & $\underline{5}$ to $\underline{20}$ & 0.079 & 0.076 & 1.29 \\
\hline 159 & Diabase, visible torbernite & $\underline{5}$ to $\underline{7}$ & .037 & .041 & 1.00 \\
\hline 163 & do. & $\underline{3}$ to $\underline{5}$ & .035 & .042 & 0.80 \\
\hline 137 & Basalt, visible torbernite & 9 to 17 & .018 & .017 & 2.58 \\
\hline 176 & do。 & 5 to $\underline{20}$ & .079 & .085 & 1.65 \\
\hline 170 & Latite, visible torbernite & $\underline{3}$ to $\underline{8}$ & .051 & .064 & 0.90 \\
\hline
\end{tabular}

Although no uranium minerals were seen in several of the samples containing an abnormal amount of uranium, such radioactive rock and vein material are also highly iron stained in most places, suggesting that the uranium may be associated with hydrous iron-oxide.

Nearly all of the samples that contain more than 0,01 percent uranium were taken in altered mafic rock near a quartz-pyrite vein. The samples that are exceptions to this generalization were taken from material within the quartz-pyrite veins or in fractures near granite. The veins are highly iron-stained and locally contain quartz in small amounts. This intense iron stain, which is believed to be indicative of oxidized pyrite in the near-surface parts of the veins, affects the argillized and sericitized wall rock and granite as much as 3 feet from the vein.

Radioactivity on the Blue Jay claim was recorded with a beta-gamma counter. The radioactivity of each type of rock was tested by recording the minimum and maximum fluctuations of the rate-meter needle for approximately 30 seconds, with the probe held 4 to 5 inches from the rock surface. The average reading for most of the relatively unaltered rocks was about 1 to 7 divisions on the 0.02 scale. This corresponds to about 0,001 to 0,003 percent uranium in samples taken nearby. 
Forty-four samples were collected during the examination. Channel samples were cut in most areas of abnormal radioactivity and several grab samples were taken in relatively unaltered rock showing minimum radioacrivity. Minimum and maximum rate-meter readings were recorded for many of the samples (table 5) with the probe held about 1 inch from the rock.

On the Blue Jay claim both granite and rhyolite normally contain 0,001 to 0,002 percent uranium. Within a few inches of fractures and veins the granite may contain several times this amount. A sample of weathered granite with torbernite was submitted by the owner and found to contain 0.83 percent uranium. Basalt and diabase contain about 0,001 to 0,005 percent uranium except within or near fractures and veins where they may contain as much as 0,085 percent. The intensely altered latite contains from 0,006 to 0.064 percent uranium. All aphanitic dikes are altered and contain as much as 0.11 percent uranium. The total area of uranium-bearing rocks on the Blue Jay claim is small. The 3-1/2 foot aphanitic dike is about 90 feet long, as determined on the basis of abnormal radioactivity in the soil along the indicated strike. Uranium content of the diabase in the northwestern bulldozer cut (fig。 9 ) is abnormally high。 The highest uranium concentration in this diabase is in an area about 25 feet square where it is cut by an iron-stained vein or fracture.

Although the latite apparently has a high uranium content, the richest uranium concentrations in this rock are along an iron-stained fracture zone in the southwestern bulldozer cut

\section{Suggestions for prospecting}

The results of sampling indicate that no large deposits of uranium ore are available. If prospecting is done, it should be concentrated along the intersections of intermediate and basic dikes with quartz-pyrite fissure veins, and also along the radioactive aphanitic dike exposed in the northwestern bulldozer cut.

\section{Reserves}

Results of sampling suggest that at six localities the uranium-bearing rock on the property, contains between 0,01 and 0,05 percent uranium. The largest deposit is in and along the aphanitic dike in the northern bulldozer cut (fig,9)。 


\section{Monarch No. 2 claim}

The Monarch No, 2 claim is in $\sec _{0} 19, T_{0} 20 \mathrm{~S}_{\circ}, \mathrm{R}_{\mathrm{o}} 15 \mathrm{~W}_{\circ}$, Grant County, $\mathrm{N}_{\circ}$ Mex, about 4 miles west of the settlement of White Signal, and is owned by C.E。 Russell, White Signal (fig. 1). Brief examination of the claim was made by $H_{0} L_{0}$ Bauer, $\mathrm{Jr}_{\mathrm{o}}$ 。 on May 22, 1950 。

A milk-white rhyolite dike, which strikes $\mathrm{N}_{0} 45^{\circ} \mathrm{E}_{0}$, intrudes granitic country rock on this claim. A massive quartz vein parallels the dike, which locally has been silicified and cut by quartz stringers. Fracture surfaces in the dike are stained by limonite

A prospect pit, 15 feet long and 2 feet deep, has been excavated in the rhyolite dike. A few autunite crystals were observed within the rhyolite, but none could be seen on the fracture surfaces. The radioactivity of the rhyolite caused a deflection of 5 to 15 divisions on the 0.2 scale of a Geiger-ounter. The quartz was not radioactive. A grab sample, BJ-7-14, was taken from the dump and found to contain 0.011 percent uranium.

The Money Maker and Wild Irishman claims are southwest of the Monarch No. 2 claim; they include the same rhyolite dike and associated massive quartz vein but show no abnormal radioactivity.

Tunnel Site No。 1 claim

The Tunnel Site No, 1 claim (fig, 1) is in the SE $1 / 4 \mathrm{NE} 1 / 4 \mathrm{sec}_{0} 26, \mathrm{~T}_{0} 20 \mathrm{~S}, \mathrm{R}_{0} 15 \mathrm{~W}_{0}$, New Mexico principal meridian. It is reached by about 1-1/2 miles of graded dirt road that turns south from State Highway 180 at White Signal。 $N_{0}$ Mex $_{a}$

The claim is owned by $E_{\circ} B_{0}$ Killion of Silver City, $N_{0}$ Mex, and was examined briefly by $H_{0} C_{0}$ Granger and $\mathrm{H}_{\circ} \mathrm{L}_{\circ}$ Bauer $_{\circ} \mathrm{Jr}_{\circ}$, on April 1, 1950。 Development work consists of a discovery shaft 10 feet deep and a 250-foot adit approximately 75 feet west of the shaft. Two winzes, 20 to 40 feet deep respectively, were sunk about 90 feet and 110 feet from the portal of the adit and short cross cuts branch from the adit near the face.

The rocks on the claim are medium-grained, gray, pre-Cambrian granite cut by greenish-gray rhyolite dikes. The discovery shaft was sunk in bleached, argillized granite near a rhyolite dike. Hydrothermal clay veins, 1 to 4 inches thick, having no preferred orientation, cut both the granite and rhyolite in and near the 
shaft. The clay appears to be of the kaolin type and contains no metallic minerals. The limonite-stained cavities in the vein may indicate the former presence of disseminated pyrite.

The adit was driven $\mathrm{N}, 30^{\circ} \mathrm{E}$, along a granite-rhyolite contact and cut several faults and vein zones. The veins cut by the adit are about 1 to 2 inches thick and are slightly iron stained. They appear to be oxidized quartz pyrite veins.

The shaft and adit were traversed with a Geiger-Mueller counter. All measurements were made with the probe beta-shield open. The radioactivity on the surface averaged about 5 divisions on the 0.2 scale in the shaft and throughout the adit. An area about 2 feet high and 3 feet long on the west wall, about 45 feet from the portal of the adit, was abnormally radioactive. When the probe was placed on the wall,

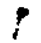
a maximum deflection of 7 was noted on the 2.0 scale. A channel sample the length of the radioactive zone assayed 0.018 percent equivalent uranium and 0.001 percent uranium.

Uncle sam silver mines

The Uncle Sam silver mines are in sec, 32, $T_{0} 20 \mathrm{~S}_{0}, \mathrm{R}_{\circ} 14 \mathrm{~W}$. New Mexico principal meridian, in the White Signal district, Grant County, $\mathrm{N}_{\circ}$ Mex。(fig。 1). They were visited in March 1950 by $\mathrm{H}_{\circ}$ L。 Bauer, Jr. Ownership of the properties is not known.

The mines are a series of abandoned shafts, adits, stopes and prospect pits extending for about onehalf mile along a shear zone that ranges from 1 to 6 feet in width, trends $N_{0} 40^{\circ}-45^{\circ} W_{0}$, and dips $70^{\circ}$ $85^{\circ} \mathrm{SW}$

Country rock at the mines is pre-Cambrian granite. Quartz and sulfide minerals fill fractures in a shear zone in the granite. A zone of iron-stained granite 2 to 6 feet wide is coextensive with these veins.

Abnormal radioactivity was noted in some specimens of sulfide-bearing vein material from the dump. These specimens gave readings of 8 to 12 divisions on the 0.2 scale of a survey meter, when the probe was placed in contact with the vein material. The background was 5 divisions on the 0.2 scale. At the portal of an adit 500 feet southeast of the main shaft, a silicified fracture 1 foot wide registered 10 to 12 on the 0.2 scale. A 2-inch limonite vein in a small pit approximately 1500 feet northwest of the main shaft, registered from 2 to 5 on the 2.0 scale. No samples were taken of the abnormally radioactive areas because of their small size and because the field readings indicate that the deposits contain less than 0.01 percent equivalent uranium. 


\section{Black Hawk district}

The Black Hawk district is in secs, 20,21,28, and 29, $T, 18 \mathrm{~S}_{0}, \mathrm{R}_{0} 16 \mathrm{~W}$, , New Mexico principal meridian, about 20 miles by road from Silver City, N. Mex (fig. 1). The district is reached by a dirt road which extends south from $U$, S. Highway 260 about 13 miles northwest of Silver City。

On March 19, 1950, $H_{0}$ C。 Granger and $H_{0} L_{0}$ Bauer, $\mathrm{Jr}_{\mathrm{o}}$, made radiometric traverses of the Black Hawk mine dump and dumps from other mines on the same vein. Rocks along Black Hawk Canyon were tested for a distance of about 2 miles south from the Black Hawk mine.

Additional information was compiled from the files of the $U_{0} S_{0}$ Bureau of Mines in Silver City, $N_{0}$ Mex.

The Black Hawk district was discovered in 1881 and $\$ 1,500,000$ worth of silver was produced in seven years. About half of this amount came from the Black Hawk mine; the remainder came from the Alhambra, Rose, and Hobson mines, all within a mile of the Black Hawk mine. Mining ceased entirely in 1893 and the mines remained idle until 1917, when the Black Hawk mine was reopened for exploratory purposes. Reports do not show that any ore was mined at this time. After 1918 there was little interest in the district, although Leach (1920, p. 989) mentions pitchblende from the Black Hawk district

In 1948 the $\mathrm{U}$ 。 $\mathrm{S}$. Bureau of Mines became interested in the district. Albert A. Leach, owner of the Alhambra mine, submitted to the Bureau old reports on the mines of the district and also several specimens that contained silver, nickel, cobalt, and uranium (pitchblende). The $U$ 。 $S$ 。 Bureau of Mines made a brief examination of the district on July 24,1948 , and collected two samples (table 6 ), which were not assayed for uranium.

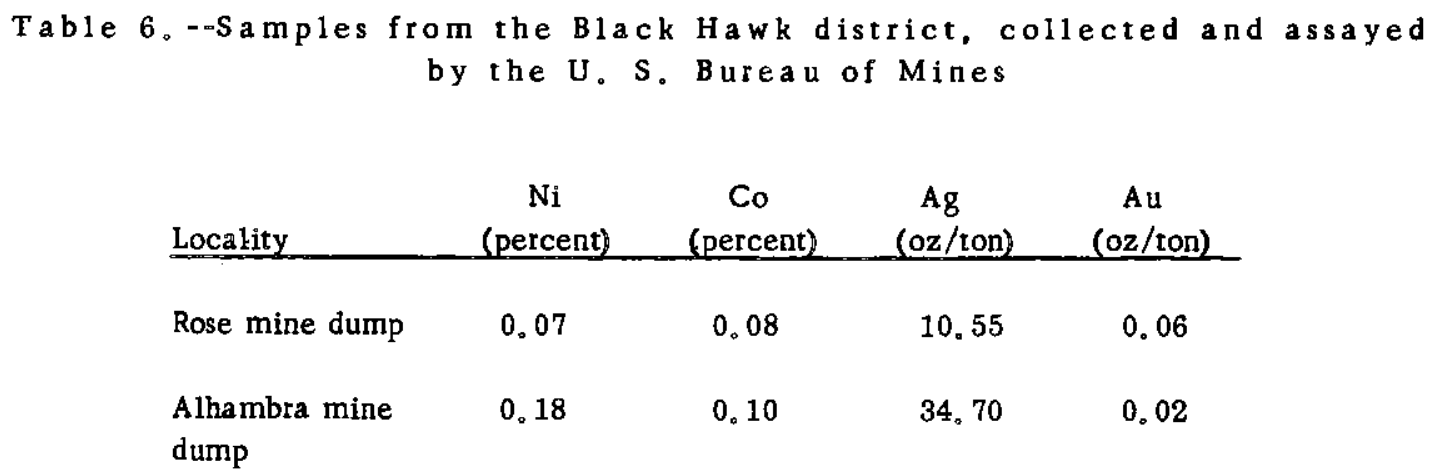


General geology

According to a report on the Black Hawk mine by Weed (1918), the oldest rock in the vicinity of this mine is a coarsely porphyritic gneiss of probable pre-Cambrian age. This rock contains large feldspar crystals in a groundmass of biotite and, locally, of quartz. The gneiss is cut by aplitic dikes that grade into feldspar pegmatites. Dikes related to a large intrusion of monzonite porphyry are present near the Black Hawk mine.

According to Weed, (1918), a pink granite, a dark-colored quartz diorite, and a rhyolite dike occur near the mine. Monzonite porphyry and gneiss were found in the mine and both rocks are cut by carbonate veins, but only in the gneiss are the veins ore-bearing.

\section{Ore deposits}

The veins in the Black Hawk district are well defined where fresh, but rather inconspicuous in exposures at the surface. They cut the rocks within an area of nearly 4 square miles.

According to a report by $A_{\text {. }} A_{\text {. Leach }}(1917)$, the gangue in the vein is composed of partly silicified carbonates. The silicified gangue is commonly a fine-grained jasperoid. Pyrite, galena, sphalerite, and chalcopyrite are associated in the vein with niccolite, nickel-skutterudite, smaltite, native silver, and argentite.

Pitchblende had been reported to occur in the Black Hawk and Alhambra mines, and the Black Hawk dump was carefully examined for vein material, but a few specimens of carbonate gangue containing small amounts of metallic sulfide were all that could be found.

The occurrence of cobalt-, nickel-, and silver-bearing minerals in a gangue of carbonates and silicified carbonates suggests a similarity between the mineral assemblage in the Black Hawk district and that in many similar deposits known to contain pitchblende.

$$
\text { Description of properties }
$$

\section{Black Hawk mine}

The Black Hawk property consists of 14 claims, 8 of them patented, owned by the Black Hawk Consolidated Mines Co., Milwaukee, Wis. Ira Wright, of Silver City, $\mathrm{N}_{\circ}$ Mex $\mathrm{x}_{\circ}$, is general manager, 
The mine includes 4 vertical shafts and one inclined shaft, all caved and inaccessible. According to old reports, the main shaft extends from the surface to the eighth level 450 feet below the surface and a winze on the eighth level extends 150 feet deeper, giving a total depth of 600 feet to the mine workings. The vein is exposed on the second level for 434 feet to the east and 80 feet to the west of the shaft. The Black Hawk mine is reported to have produced $\$ 650,000$ in silver between 1881 and 1889 .

\section{Alhambramine}

The Alhambra mine is on a group of 5 patented and 3 unpatented claims owned by Albert A. and Frances $I_{0}$ Leach, Lordsburg, No Mex. The main shaft is reported to be 400 feet deep and the mine contains several hundred feet of horizontal workings.

Records show that the Alhambra mine produced $\$ 400,000$ in silver prior to $1893_{\text {. }}$

\section{Rose mine}

The Rose mine is on a patented claim owned by Mrs。 Elizabeth J。 McCabe, Pasadena, Calif. At present, the workings are caved and inaccessible. It is reported that the main shaft is 200 feet deep. Levels are at 50, 100, 150, and 200 feet.

Past production is reported to be $\$ 140,000$ in silver.

\section{Hobson mine}

No description of the Hobson mine is available.

\section{Radioactivity}

In July 1949 the engineers of the $U_{0} S_{0}$ Bureau of Mines examined the dump of the Alhambra mine with a Geiger counter. They found that one small pile of ore was slightly radioactive. The U. S. Bureau of Mines also tested several specimens of cobalt-nickel ore from the Alhambra mine which had been submitted by Albert A. Leach. One specimen was found to be very radioactive, probably because of the presence of pitchblende. 
Granger and Bauer tested a specimen of native silver from the Black Hawk mine, owned by Ira Wright, Silver City, N。Mex. The specimen, about 60 to 80 percent native silver, registers 15 divisions on the 2. 0 scale of a Geiger counter. The average background was about 4 divisions on the 0.2 scale.

No radioactivity over twice normal background was observed on the Black Hawk or nearby dumps along the Black Hawk vein. One small dump about a mile south of the Black Hawk mine, on the west wall of the canyon, registered 10 divisions on the 0.2 scale. The country rock showed no abnormal radioactivity.

\section{Other occurrences}

\section{Hines no. 1 prospect}

The Hines deposit is in the NE $1 / 4 \mathrm{sec}, 34, T, 21 \mathrm{~S}_{0}, \mathrm{R}_{\circ} 14 \mathrm{~W}$, , about 13 miles by road southeast of White Signal. It is owned by Joe Frost of White Signal and was discovered by Mr. Frost and Charles Russell of Tyrone in March 1950。 It may be reached from White Signal by traveling 1.5 miles east along the White Signal-Whitewater road, then turning south to the Royall Ranch. Beyond the ranch the road is indefinite and inquiry should be made for directions to the property. The deposit was examined by Harry C. Granger, Herman $L_{\circ}$ Bauer, $I_{0}$, and Elliot Gillerman in April 1950; 1ater it was re-examined and mapped by Elliot Gillerman in June 1950 .

The Hines deposit is in Bliss sandstone (?) of Cambrian age. The exposure is 250 to 300 feet wide, and is surrounded by alluvium on all but the northwest side, where it is in fault contact with pre-Cambrian granite. This fault strikes $\mathrm{N}_{0} 30^{\circ} \mathrm{E}$, and seems to dip steeply northwest.

The Bliss sandstone (?), in this vicinity, consists of medium-grained, well-cemented, silicified white quartzite, grayish-green, ferruginous quartzite, gray quartzite, and a bed of brown, medium-grained limestone 10 feet thick, that contains gastropod fragments. These rocks strike northwest and dip steeply to the northeast in the vicinity of the pits. A small, northwesterly-trending fault cuts the sedimentary rocks a short distance north of the pits (fig, 10).

Fluorite and autunite (?) occur in breccia along a nearly vertical shatter zone in the quartzite that strikes $N_{0} 85^{\circ}$ E. A subsidiary breccia zone, which strikes $N_{0} 50^{\circ} W_{0}$, branches southeastward from the main zone. Scheelite occurs in a similar breccia zone that strikes about N. $75^{\circ} \mathrm{E}$. It is close to, but not 


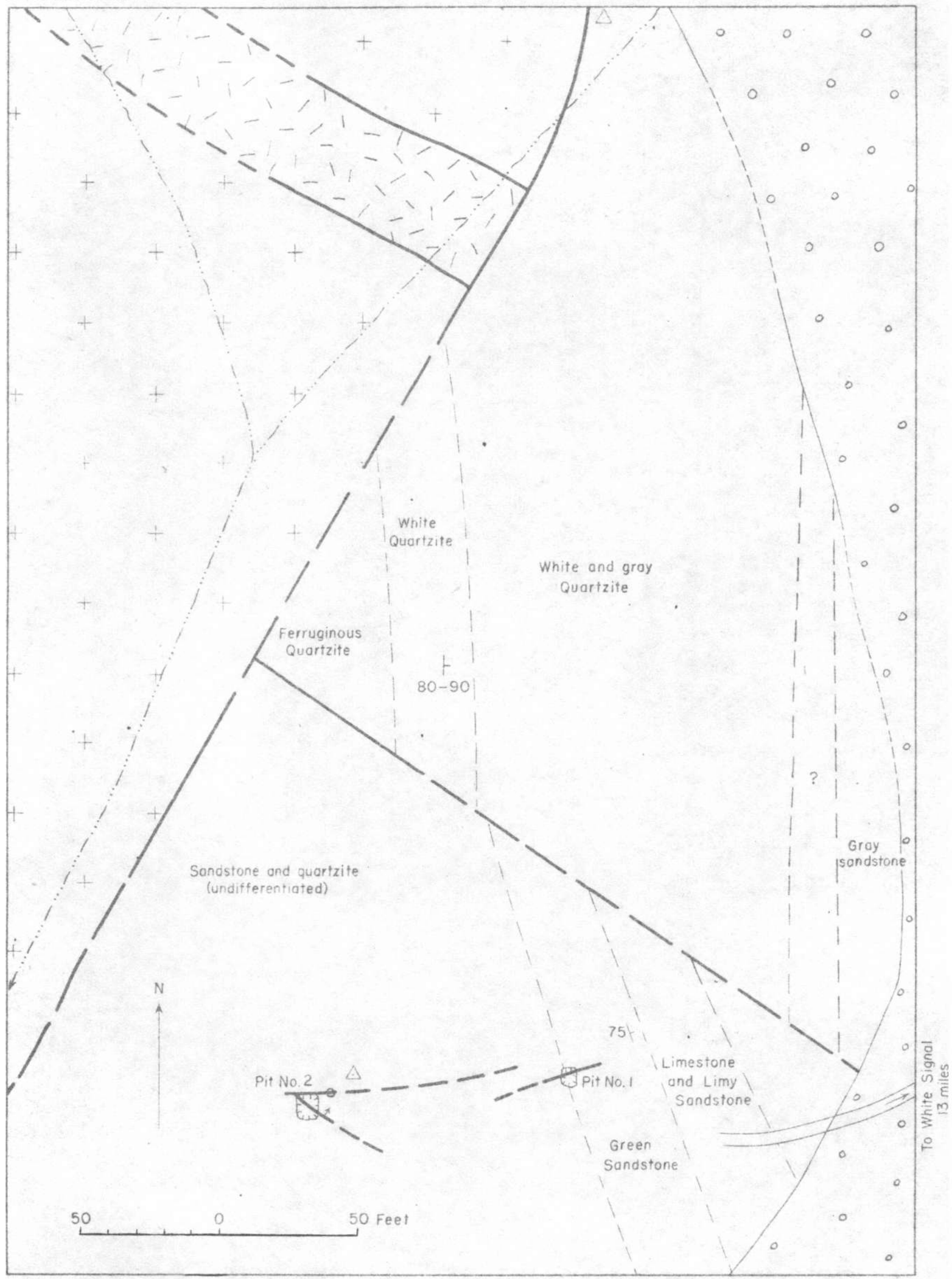

Geology by Elliot Gillerman, June 1950

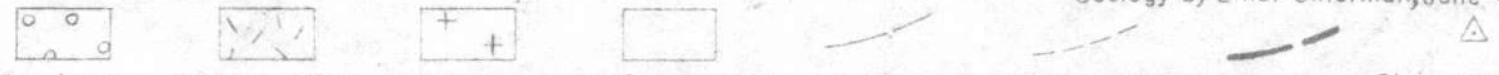

Overburden Diabase dike Granite Bliss? sandstone contact inferred contact Fault Claim monument (dashed where approximate) (dashed where approximate)

FIGURE IO-GEOLOGIC SKETCH MAP OF THE HINES PROSPECT, GRANT COUNTY, NEW MEXICO 
contiguous with, the fluorite-autunite zone. The fluorite is white, violet, or dark purple; it occurs as fissure fillings and matrix in the breccia in pit No。2. Rare, small crystals of a yellow, fluorescent material, tentatively identified as autunite, coat fracture surfaces on the quartzite in this pit, but they are seldom closely associated with the fluorite. No radioactive material was found in pit No. 1 .

The age of mineralization is unknown; the paragenetic relationship of the fluorite and the autunite (?) are inconclusive, but the autunite (?) appears to be later.

Radioactive breccia exposed in pit No, 2 gave a maximum reading of 5 divisions on the 2.0 scale of a beta-gamma counter. No abnormal radioactivity was noted in pit No。1.Two channel samples across the breccia zone, one in the east end and one in the west end of pit No. 2 , both contained 0.004 percent uranium (table 7). A grab sample, submitted by the owner, assayed 0.027 percent equivalent uranium。

Table 7.--Results of sampling, Hines No。 1 prospect, Grant County. New Mexico

$\begin{array}{lclll}\begin{array}{l}\text { Sample } \\ \text { number }\end{array} & \text { Locality } & \text { Description } & \begin{array}{l}\text { Equivalent } \\ \text { uranium } \\ \text { (percent) }\end{array} & \begin{array}{c}\text { Uranium } \\ \text { (percent) }\end{array} \\ \text { HLB-14-134 } & \text { Pit no. } 2 & \begin{array}{l}\text { Quartzite breccia and fluorite。 } \\ \text { Channel sample 1,5 feet long }\end{array} & 0.005 & 0,004 \\ \text { HLB-14-135 } & \text { do. } & \begin{array}{l}\text { Quartzite breccia and fluorite。 } \\ \text { Channel sample } 3 \text { feet long }\end{array} & .006 & .004 \\ \text { HLB-14-136 } & \text { Pit no.1 } & \text { Quartzite breccia } & .001 & .001\end{array}$




\section{Langford prospect}

The Langford deposit is in the $S 1 / 2 \sec _{0} 25, T_{0} 22 S_{0}, R_{0} 16 \mathrm{~W}$, about 23 miles by road south of White Signal; it can be reached by driving $19_{a} 5$ miles south from White Signal on the Separ road, then turning west for 3,5 miles on a dirt road to the prospect. This deposit was discovered by Charles Russell of Tyrone and was undeveloped at the time of this report. It was examined and mapped by Elliot Gillerman in April and June 1950。

The deposit is in a sillicified breccia zone cutting fine-grained, grayish-pink, pre-Cambrian granite. Numerous pegmatite dikes, 2 inches to 2 feet wide ${ }_{0}$ cut the granite; south and southeast of the deposit rhyolite and diabase dikes also intrude the granite.

Ore minerals consist of dark purple fluorite and a yellow uranium mineral possibly autunite associated with pink calcite in a silicified breccia zone. The breccia is exposed for about 150 feet along the north bank of a small creek in a fault that strikes $\mathrm{N}_{\circ} 35^{\circ} \mathrm{W}_{\circ}$, and dips $65^{\circ} \mathrm{SE}$. The fluorite and autunite (?) are limited to the middle 50 feet of the exposure, but pink calcite is found along the entire exposed length of the fault. The mineralization is spread throughout the $21 / 2$ to $31 / 2$-foot zone of breccia but is most concentrated on the footwall side of the fault. Fluorite occurs as tiny, violet to dark-purple crystals in veinlets less than half an inch wide. The bright-yellow autunite (?) lines cavities in the breccia less than 5-mm in diameter. The dark-purple fluorite was found to be radioactive。

The radioactive breccia zone gave a maximum reading of 5 divisions on the 2.0 scale of a beta gamma counter:

\section{Uranium occurrences not discussed}

The following reported uranium occurrences in Grant County have not yet been studied by the $U_{0} S_{0}$ Geological Survey and are not included in this report: many small deposits in the White Signal district, some of which are included in the report by Keith (1945); torbernite from the Chino disseminated copper pit near Santa Rita; autunite in the Eureka district, in the Little Hatchet Mountains; and radioactive xenoliths in Tertiary lavas in Little Gallina Canyon in the Black Range。Two samples of cherty material from Little Gallina Canyon were submitted by $C 。 H_{\circ}$ Rogers to the $U_{\circ} S_{\circ}$ Geological Survey for analysis。They contained 0,068 and 0.016 percent uranium respectively。 


\section{LITERAT URE CITED}

Davidson, $C_{0} F_{0}, 1949$, A prospector's handbook to radioactive mineral deposits: Dept. of Sci. and Ind。 Research, Geol. Survey and Museum, London, 28 pp.

Gillerman, Elliot, 1952, Fluorspar deposits of the Burro Mountains and vicinity, New Mexico: U. S. Geol. Survey Bull。973 F, 27 pp。

Hernon, R。 M。 1949, Geology and ore deposits of Silver City region, New Mexico: West Texas Geol. Soc. Guidebook, field trip No。3, 42 pp.

Kerr,$P_{\circ} F_{a}$, Kulp, J。 L。 , Patterson, C. E., and Wright, R。 Jo, April 1950, Hydrothermal alteration at Santa Rita, New Mexico: Geol. Soc America Bull. , vol 61 , no。 4, pp。 275-347.

Kidd, D . F。, and Haycock, $\mathbf{M}_{*} \mathbf{H}_{\circ}$, June 1935, Mineragraphy of the ores of Great Bear Lake: Geol. Soc. America Bull。 vol。 46, pp. 879-960。

Leach, F。 $\mathrm{S}_{\mathrm{a}}, 1920$, Radium ore discovered in the White Signal district, New Mexico: Eng, and Min. Jour 。 vol. 109, P.989。

Lindgren, Waldemar, Graton, $L_{0} C_{0}$, and Gordon, $C_{0} H_{0}, 1910$, The ore deposits of New Mexico: U。 S. Geol。Survey Prof。Paper 68, 361 pp.

Paige, Sidney, 1916, Silver City, New Mexico: U。 S。Geol。Survey Geol。 Folio 199, 20 pp.

Rankama, Kalervo, and Sahama, Th, G. 1950, Geochemistry, The University of Chicago Press, 912 pp.

\section{UNPUBLISHED REPORTS}

Bauer, $H_{\circ} \mathrm{L}_{\circ}, \mathrm{Jr}_{\circ}$, June 1950, Apache Trail uranium prospect, White Signal district, GrantCounty, New Mexico: U。 S。Geol。Survey Trace Elements Mem。 Rept。121, 11 pp.

- June 1950, Radioactivity at the Uncle Sam silver mine, White Signal district, Grant County, New Mexico: U。 $S_{\circ}$ Geol。Survey Trace Elements Mem。Rept。122, 14 pp.

December 1950, Autunite at the Monarch No。2, Money Maker and Wild Irishman claims, White Signal district, Grant County, New Mexico: $U_{\circ} S_{\circ}$ Geol。 Survey Trace Elements Mema . Rept, 160, 2 pP。

Gillerman, Elliot, and Granger, $H_{0} C_{0}$, October 1951, The Hines and Langford uraniferous fluorspar prospect, Grant County, New Mexico: U。S. Geol。 Survey Trace Elements Mem。Rept, 120, 15 pp。

Granger, $\mathrm{H}_{\mathrm{o}} \mathrm{C}$. October 1950 , Preliminary Investigation of radioactivity in the Black Hawk district, Grant County, New Mexico: U. S. Geol。 Survey Trace Elements Mem。Rept。118, 7 pp。 
Granger $_{\mathrm{p}} \mathrm{H}_{\mathrm{o}} \mathrm{C}_{0}$, and Bauer, $\mathrm{H}_{\circ} \dot{\mathrm{L}}_{0}, \mathrm{Jr}_{\mathrm{o}}$, June 1950 , Uranium occurrences on the Blue Jay claim, White Signal district, Grant County, New Mexico: U。 $S_{\circ}$ Geol。 Survey Trace Elements Mem。 Rept。117, $21 \mathrm{pp}$.

July 1950, Results of diamond drilling, Merry Wịdow claim, White Signal district, Grant County, New Mexico: U。 S。Geol。Survey Trace Elements Mem。Rept。146, 9 pp。

December 1950 , Radiometric examination of the Tunnel Site No: 1 claim, Grant County, New Mexico: U。S。Geol。Survey Trace Elements Mem。Rept。134, 3 pp。

June 1951, Uranium occurrences on the Merry Widow claim, White Signal district, Grant County, New Mexico: $U_{0}$ 。 Geol。Survey Trace Elements Invs。Rept。157, 41 pp。

Keith, $\mathrm{S}_{\circ} \mathrm{B}_{\mathrm{o}}$, 1944, Reconnaissance of the White Signal, Black Hawk, and San Lorenzo districts, and the Swanson-Lauer property, New Mexico: Union Mines Development Corporation Report, 19 pp.

1945, Report on detailed examination of S-37 accurrences in the White Signal and associated districts, New Mexico: Union Mines Development Corporation Report, 62 pP.

Leach, $A_{0} A_{0}$, March 1917, Report on the geology of the Black Hawk mine, Unpublished report。

Weed $W_{\circ} H_{\circ}, 1918$, Report on the properties of the Black Hawk Mining and Milling Company, Silver City, New Mexico: Unpublished report. 


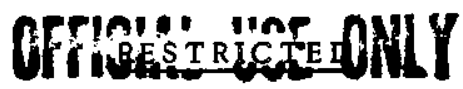

62

USGS - TEI Report I56

PART II

CONTENTS

Page

Abstract 。. . . . . . . . . . . . . . . . . 63

Reserves . . . . . . . . . . . . . . . . . . 63

Methods used. . . . . . . . . . . . . 64

Recommendations . . . . . . . . . . . . . . . 65 
The only property in Grant County with uranium reserves of ore grade is the Merry Widow mine in the White Signal district. Within the Merry Widow vein zone, close to the shaft, a bloek of ore containing five hundred tons of 0.4 percent uranium ore is indicated. Low-grade uranium mineralization has been found in more than fifty mines and prospects in the White Signal district, which suggests that reserves may be substan. tially increased by further prospecting.

The discovery of pitchblende on old dumps in the Black Hawk district indicates that it may also be a potential source of uranium ore. A considerable amount of exploration will have to be done here before any estimates of tonnage and grade of reserves can be made.

\section{RESERVES}

In Grant County only two districts, the White Signal and the Black Hawk, show indications of uranium ore. The only proven reserves are in the Merry Widow mine in the White Signal district.

These reserves were calculated by Keith in 1945 on the basis of numerous channel samples across the vein. He outlined a block of uraniferous rock 3 feet wide across the vein extending from the surface to the 130-foot level, to the eastern limits of the mine workings and from 55 feet west of the shaft on the 40 -foot level to the shaft on the 130 -foot level. For this block he estimated 1,900 tons of rock containing 0.08 percent uranium. A smaller block extending from the surface to the sixty-foot level and approximately 25 feet on both sides of the shaft was estimated to contain 500 tons of 0.37 percent uranium ore. An additional 30 tons of 0.35 percent ore were indicated ${ }_{\circ}$ An additional 2,900 tons of 0,08 percent uraniumbearing rock were indicated and an additional 4,000 tons were inferred. These same estimates were used by Granger and Bauer, but additional samples taken by them indicate that on the Merry Widow claim exclusive of the mine itself there are an additional 50 tons of 0.08 percent uranium-bearing rock inferred (table 3 , fig。2)。 


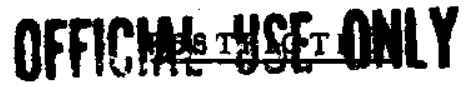

The Blue Jay claim is the second richest uranium deposit in the White Signal district and the only one outside of the Merry Widow property on which enough sampling has been done to permit estimation of reserves. The largest deposit is along the aphanitic dike in the northernmost bulldozer cut (fig.9). This body has a width of 6 feet, a length of 90 feet and an estimated depth of 45 feet. It contains an estimated 2,400 tons of rock averaging 0.05 percent uranium. An additional 15 tons of rock containing 0.05 percent uranium could be recovered from the prospect pit just west of the northernmost bulldozer cut (fig. 9).

None of the other properties in the White Signal district were sampled sufficiently to permit estimation of reserves, but abnormal radioactivity has been detected at more than fifty places in the district, and present indications are that between ten and twenty thousand tons of rock containing 0.04 to 0.1 percent uranium are available.

No estimate is possible of the uranium reserves in the Black Hawk district at the present time because all the mines are inaccessible. The presence of pitchblende in specimens from old dumps in this district, strongly suggests that explotation in this district may find uranium ore.

Estimated uranium reserves of Grant County

\begin{tabular}{ccc} 
Merry Widow claim & $\begin{array}{c}\text { Tons of high grade ore } \\
(0.3-0.4 \text { percent } U)\end{array}$ & $\begin{array}{c}\text { Tons of low grade ore } \\
(0.04-0.1 \text { percent } U)\end{array}$ \\
\cline { 2 - 3 } Measured & 500 & 1,900 \\
Indicated & 30 & 2,950
\end{tabular}

Blue Jay claim

Indicated

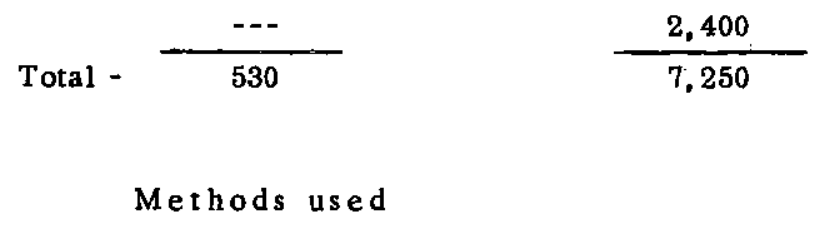

Wherever possible proportional samples were taken over the length of the radioactive exposure. Limits and classes of ore were determined by assay grades recalculated to a minimum stoping width of 3 feet. Tonnage factors of 10 cubic feet of solid rock to 1 short ton were used. All ore is divided into two classes as 


\section{OFFICHE THSE OAIY}

to the certainty of its occurrence. Measured ore is defined as ore bounded on at least two sides by sampled workings where geologic evidence assures its continuance between these boundaries。 Indicated ore is ore bounded only on one side by sampled workings where evidence of its continuation is lacking.

\section{PLANS}

Geologic field mapping by the U. S. Geological Survey, which is now in progress in the White Signal and Black Hawk districts in Grant County is expected to accomplish the following objectives: 1) delimit the regions of uranium-bearing rocks in both districts; 2) clarify regional structural patterns of uranium distribution; 3) indicate additional areas for more detailed exploration; 4) shed more light on problems of uranium ore control and distribution in the two districts. The Survey plans to continue detailed geologic mapping in both the White Signal and Black Hawk districts.

If the results of the mapping warrant, the Survey may recommend exploration in the White Signal and Black Hawk districts, as potential uranium reserves in these two districts cannot be adequately estimated without physical exploration of the known uranium occurrences. The two deposits in the White Signal district that show the most promise at this time are on the Merry Widow and the Blue Jay properties. Consideration of government exploration in this district should be limited to these two properties, pending the results of the detailed mapping of the area.

The large number of uranium shows in the districts indicate that everything possible should be done to encourage private exploration, such as providing a favorable local market for small lots of ore. 


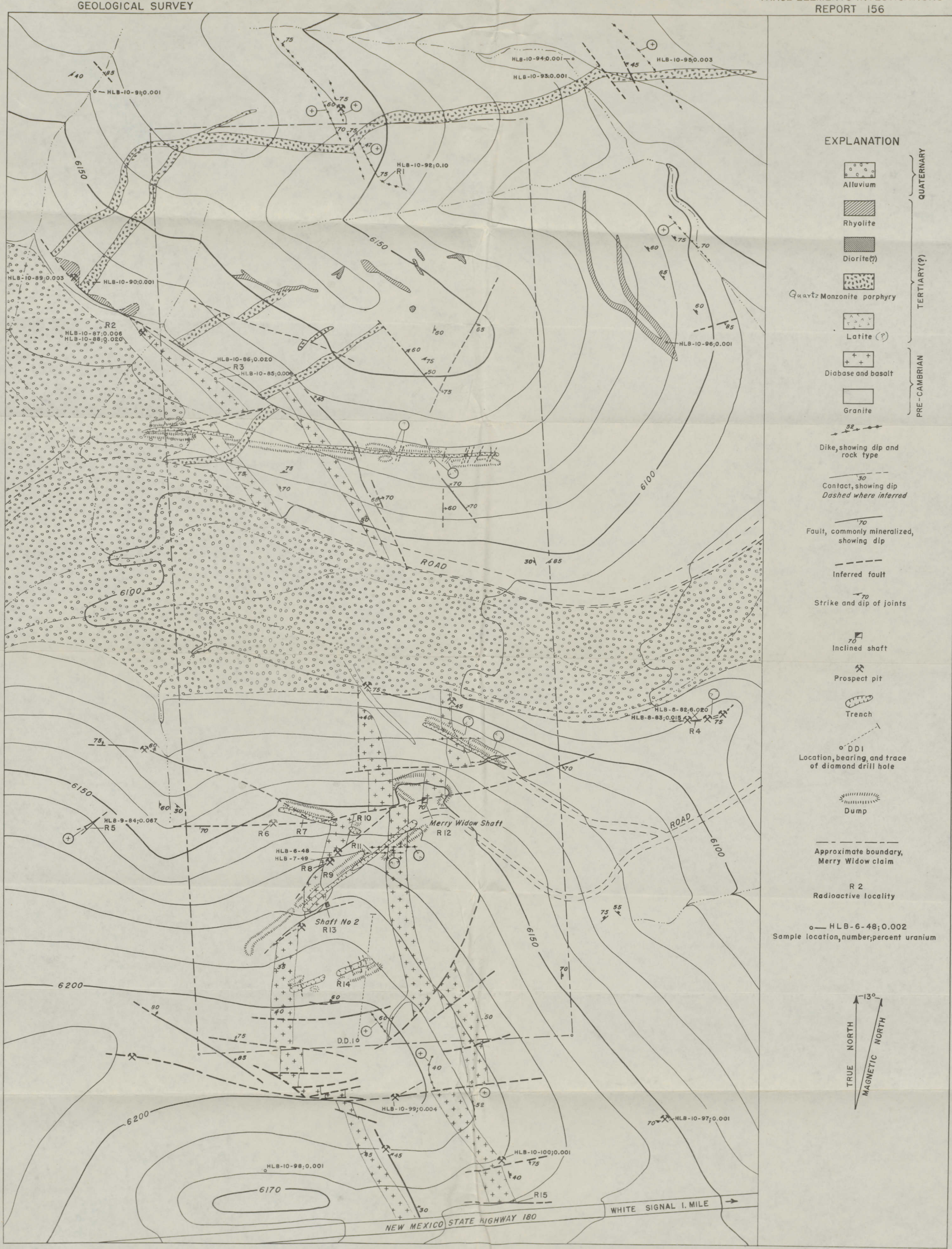

FIGURE 2.-GEOLOGIC MAP, MERRY WIDOW CLAIM, WHITE SIGNAL DISTRICT, GRANT COUNTY, NEW MEXICO. 


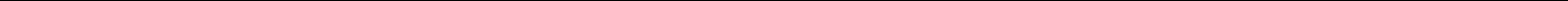




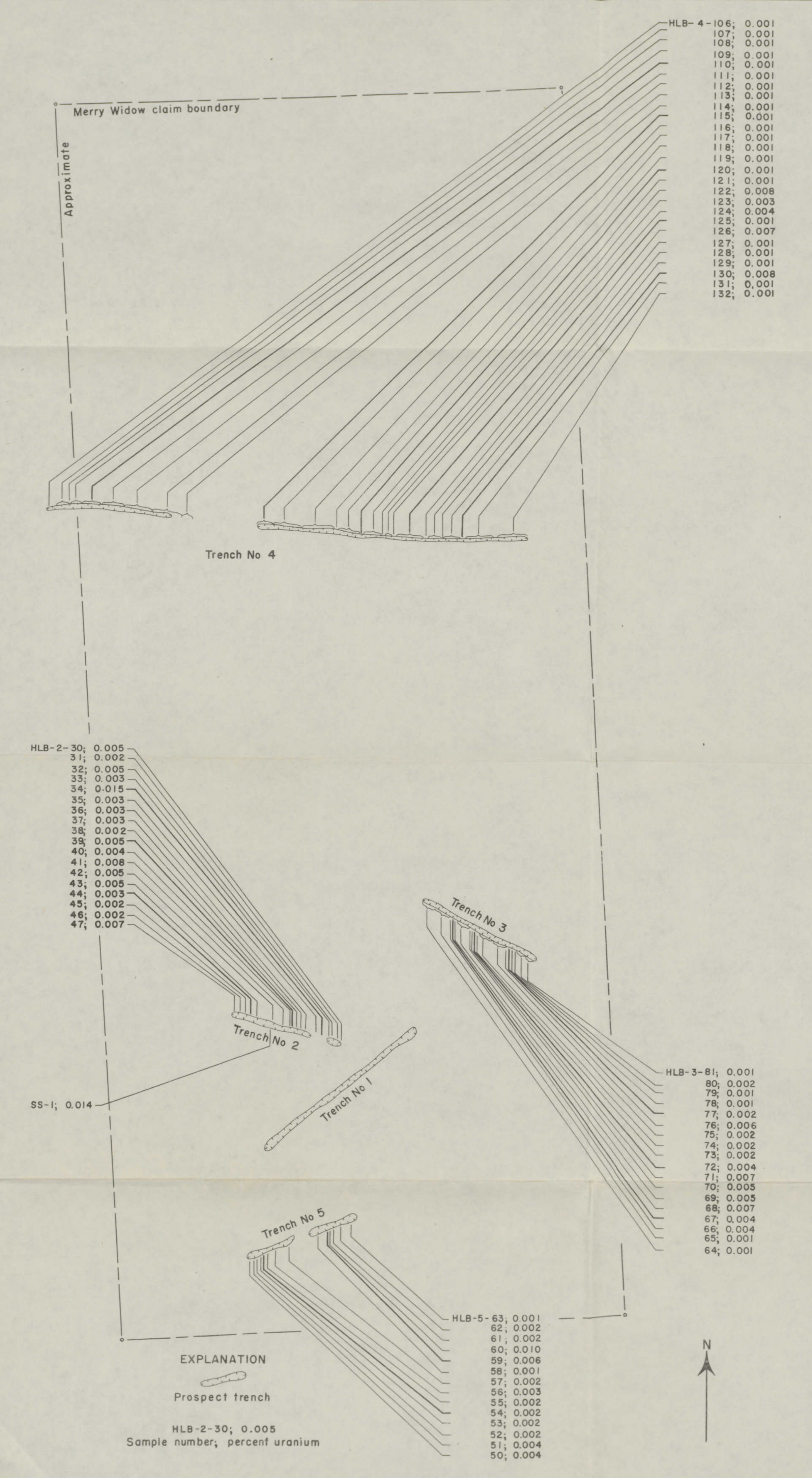

FIGURE 3-ASSAY PLAN, TRENCHES NOS. 2, 3, 4, AND 5 , MERRY WIDOW CLAIM, WHITE SIGNAL DISTRICT, GRANT COUNTY, NEW MEXICO

$$
\begin{array}{llll}
100 \quad 50 \quad 0 \quad 100 & 200 \text { FEET }
\end{array}
$$




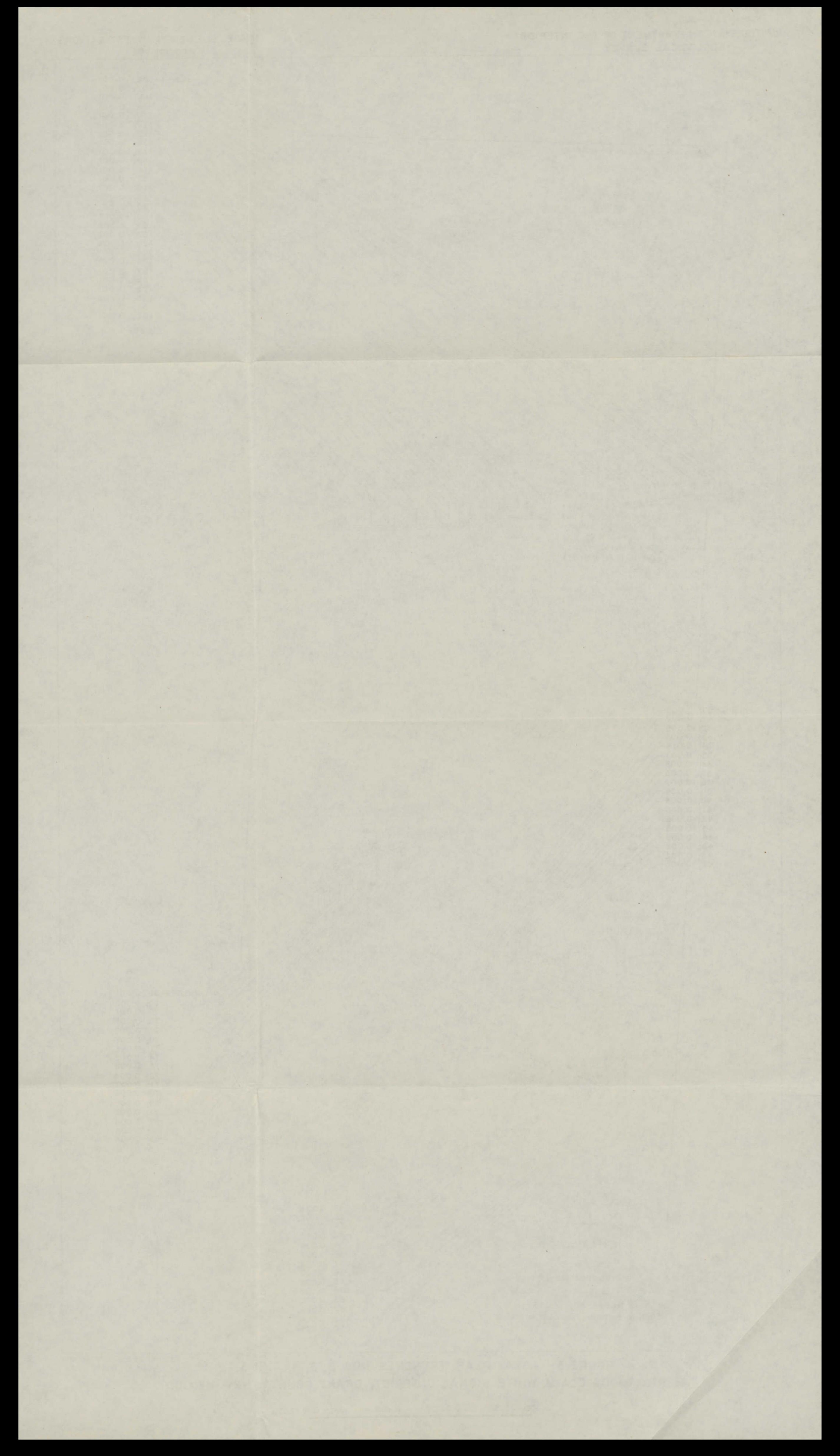




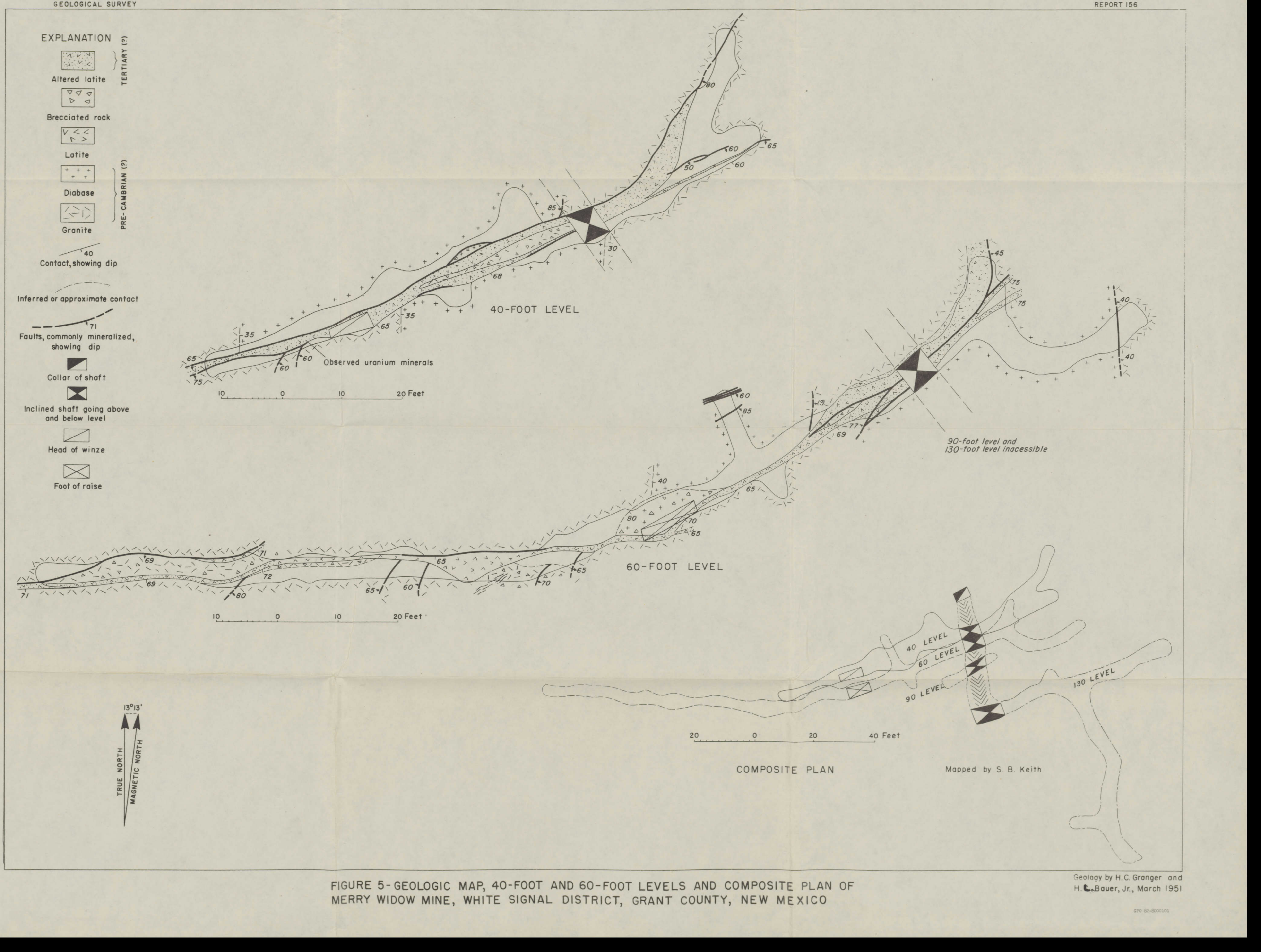





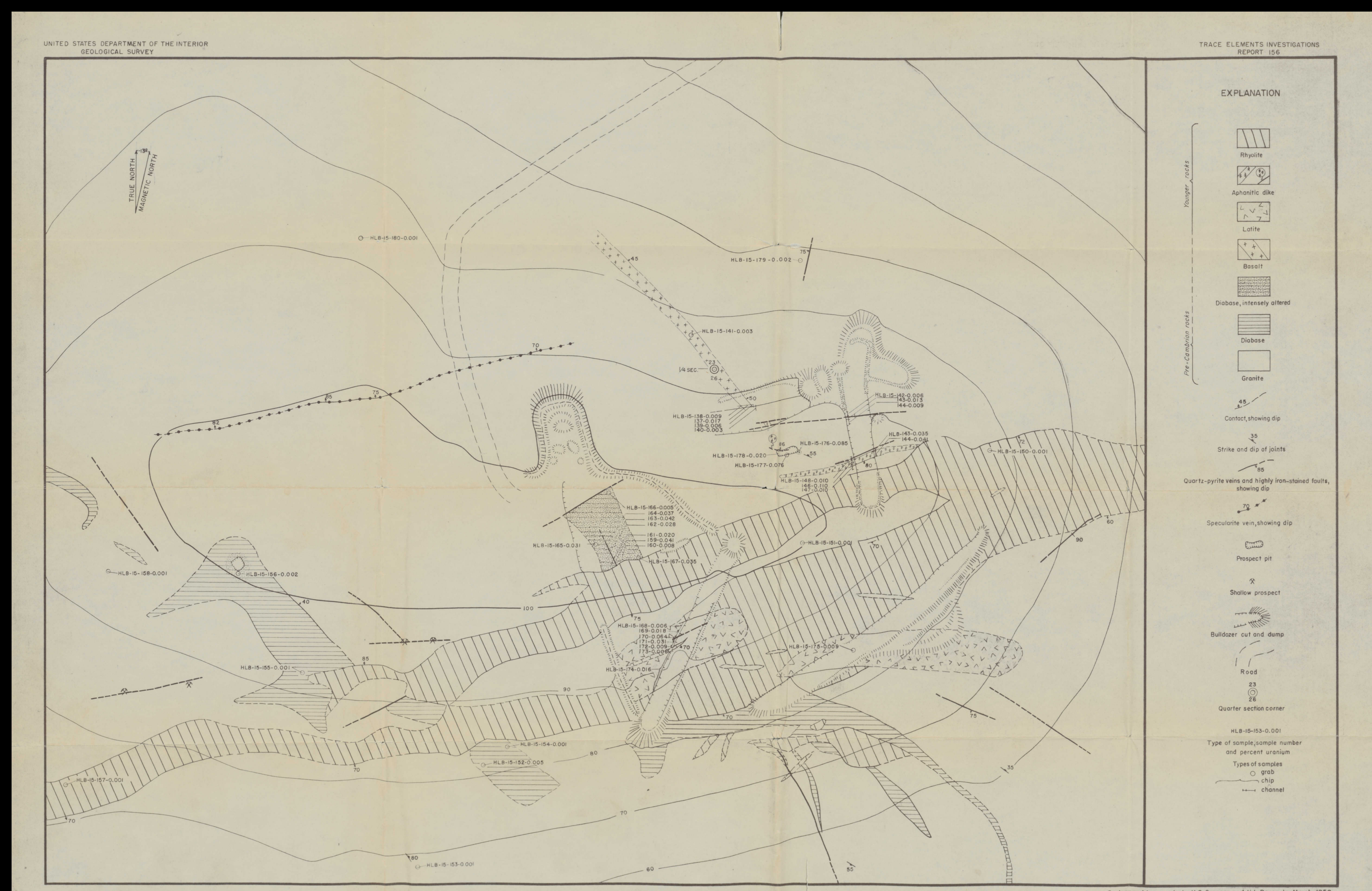

FIGURE 9. - GEOLOGIC MAP AND ASSAY PLAN OF URANIUM OCCURRENCES ON BLUE JAY CLAIM, WHITE SIGNAL DISTRICT, GRANT COUNTY, NEW MEXICO. 


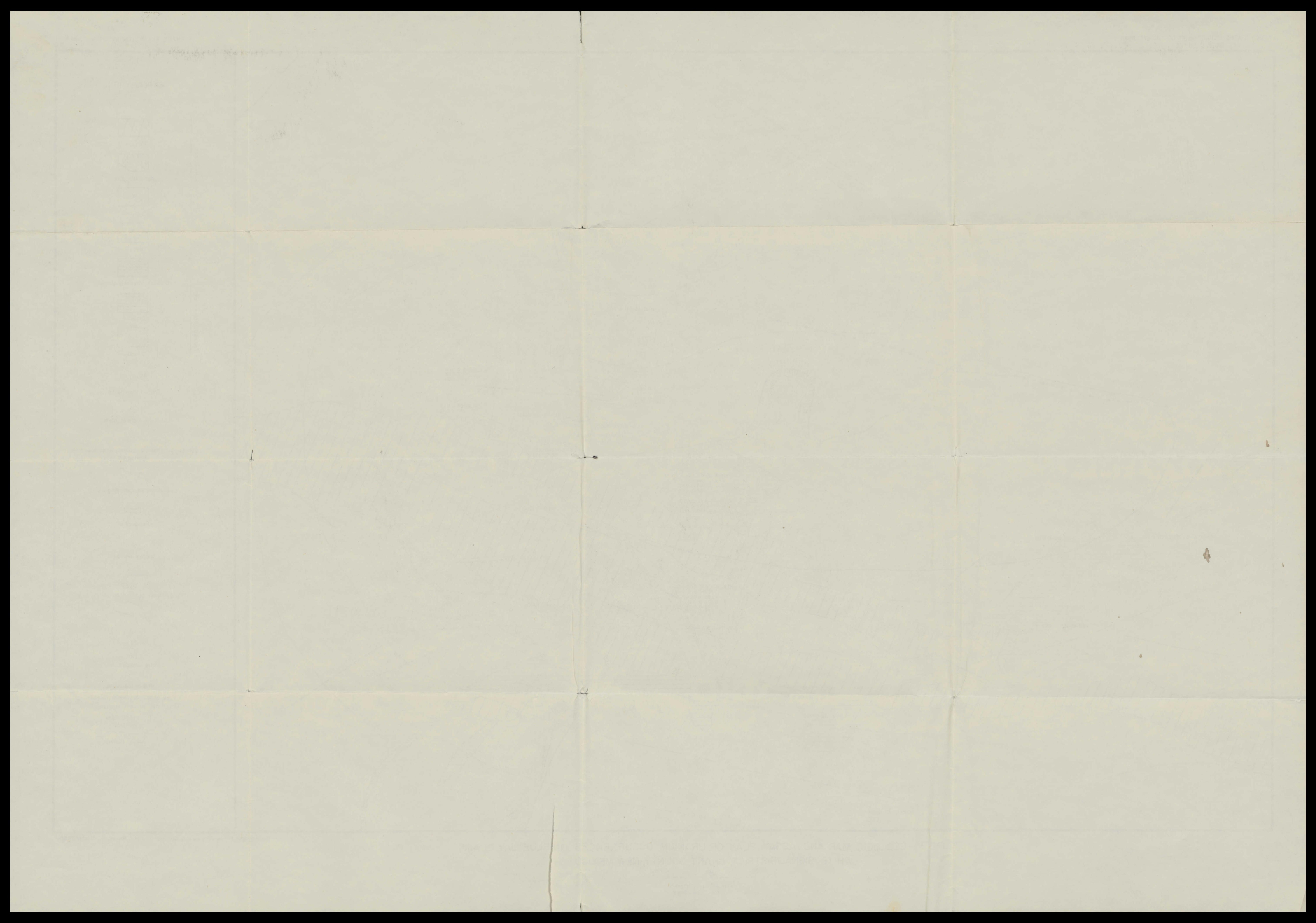



